\author{
RESEARCH ARTICLE \\ 10.1029/2020JC016258 \\ Key Points: \\ - Typhoons tend to have a three-step \\ effect on surface $\mathrm{pCO}_{2}$ : first cooling, \\ followed by mixing, and then \\ potentially biological uptake \\ - Increased air-sea $\mathrm{CO}_{2}$ flux during \\ typhoon effect periods is caused \\ primarily by high wind speed \\ - Typhoons enhance $\mathrm{CO}_{2}$ efflux by \\ $23-56 \%$ in the northern South China \\ Sea during the last decade
}

Correspondence to:

P. Yu and Z. A. Wang,

yuppe@sio.org.cn;

zawang@whoi.edu

Citation:

Yu, P., Wang, Z. A., Churchill, J., Zheng, M., Pan, J., Bai, Y., \& Liang, C. (2020). Effects of typhoons on surface seawater $\mathrm{pCO}_{2}$ and air-sea $\mathrm{CO}_{2}$ fluxes in the northern South China Sea. Journal of Geophysical Research: Oceans, 125, e2020JC016258. https:// doi.org/10.1029/2020JC016258

Received 19 MAR 2020 Accepted 28 JUL 2020

Accepted article online 3 AUG 2020

(C)2020. American Geophysical Union. All Rights Reserved.

\section{Effects of Typhoons on Surface Seawater $\mathrm{pCO}_{2}$ and Air-Sea $\mathrm{CO}_{2}$ Fluxes in the Northern South China Sea}

\author{
Peisong Yu ${ }^{1}$, Zhaohui Aleck Wang ${ }^{2}$ (D), James Churchill ${ }^{3}$, Minhui Zheng ${ }^{1}$, Jianming Pan ${ }^{1}$, \\ Yan $\mathrm{Bai}^{4}{ }^{1}$, and Chujin Liang ${ }^{4}$ \\ ${ }^{1}$ Key Laboratory of Marine Ecosystem Dynamics, Second Institute of Oceanography, Ministry of Natural Resources, \\ Hangzhou, China, ${ }^{2}$ Department of Marine Chemistry and Geochemistry, Woods Hole Oceanographic Institution, \\ Woods Hole, MA, USA, ${ }^{3}$ Department of Physical Oceanography, Woods Hole Oceanographic Institution, Woods Hole, \\ MA, USA, ${ }^{4}$ State Key Laboratory of Satellite Ocean Environment Dynamics, Second Institute of Oceanography, \\ Ministry of Natural Resources, Hangzhou, China
}

\begin{abstract}
This study assessed the effects of typhoons on sea surface $p \mathrm{CO}_{2}$ and $\mathrm{CO}_{2}$ flux in the northern South China Sea (SCS). During the passage of three major typhoons from May to August 2013, sea surface $p \mathrm{CO}_{2}$, surface seawater temperature (SST), and other meteorological parameters were continuously measured on a moored buoy. Surface water in the region was a source of $\mathrm{CO}_{2}$ to the atmosphere with large variations ranging from hours to months. SST was the primary factor controlling the variation of surface $p \mathrm{CO}_{2}$ through most of the time period. Typhoons are seen to impact surface $p \mathrm{CO}_{2}$ in three steps: first by cooling, thus decreasing surface $p \mathrm{CO}_{2}$, and then by causing vertical mixing that brings up deep, high- $\mathrm{CO}_{2}$ water, and lastly triggering net uptake of $\mathrm{CO}_{2}$ due to the nutrients brought up in this deep water. The typhoons of this study primarily impacted air-sea $\mathrm{CO}_{2}$ flux via increasing wind speeds. The mean $\mathrm{CO}_{2}$ flux during a typhoon ranged from 3.6 to 5.4 times the pretyphoon mean flux. The magnitude of the $\mathrm{CO}_{2}$ flux during typhoons was strongly inversely correlated with the typhoon center distance. The effect of typhoons accounted for $22 \%$ of the total $\mathrm{CO}_{2}$ flux in the study period, during which typhoons occurred only $9 \%$ of the time. It was estimated that typhoons enhanced annual $\mathrm{CO}_{2}$ efflux by $23-56 \%$ in the northern SCS during the last decade. As such, tropical cyclones may play a large and increasingly important role in controlling $\mathrm{CO}_{2}$ fluxes in a warmer and stormier ocean of the future.
\end{abstract}

Plain Language Summary The global ocean absorbs about 25\% of anthropogenic carbon dioxide emissions from the atmosphere and plays an important role in regulating global climate. One important question regarding estimates of carbon dioxide flux at the ocean surface is how episodic events such as typhoons affect surface seawater carbon dioxide and air-sea carbon dioxide exchange. In this study, seawater temperature generally played a primary role in controlling surface seawater carbon dioxide under nontyphoon conditions in the northern South China Sea. We found that typhoons seem to have a three-step effect on surface carbon dioxide: first cooling, which decreases carbon dioxide content, followed by vertical mixing that can bring up deep water with high concentrations of carbon dioxide and nutrients, and lastly the triggering of net uptake of carbon dioxide due to phytoplankton growth fueled by those nutrients. Increased air-sea carbon dioxide flux during a typhoon is caused primarily by high wind speed.

Typhoons enhanced carbon dioxide flux to the atmosphere by 23-56\% annually in the study region. As such, typhoons may play a more important role in the control of carbon dioxide fluxes in a warmer and stormier ocean of the future.

\section{Introduction}

The global ocean absorbs about 1.6-2.0 $\mathrm{Pg} \mathrm{C} \mathrm{year}^{-1}$ from the atmosphere, corresponding to about $25 \%$ of anthropogenic $\mathrm{CO}_{2}$ emissions (Iida et al., 2015; Takahashi et al., 2009; Wanninkhof et al., 2013). This estimate is relatively well constrained based on a compilation of directly measured oceanic $\mathrm{CO}_{2}$, obtained primarily from shipboard underway and in situ time series measurements. Measurements of $p \mathrm{CO}_{2}$ in coastal oceans have increased dramatically in recent decades. However, the estimates of $\mathrm{CO}_{2}$ fluxes in coastal systems still bear large uncertainties due to significant heterogeneity, and limited spatiotemporal coverage, of these fluxes (Bauer et al., 2013; C. T. A. Chen et al., 2015; Laruelle et al., 2014). The current understanding is that global continental shelves serve as a $\mathrm{CO}_{2}$ sink, while near-shore systems and estuaries are $\mathrm{CO}_{2}$ 
sources (Bauer et al., 2013; Cai et al., 2006; Cai et al., 2011; C. T. A. Chen \& Borges, 2009; Dai et al., 2013). Accurate assessment of the air-sea $\mathrm{CO}_{2}$ flux, and its spatiotemporal variability, in the coastal ocean is needed to improve the understanding of the coastal carbon cycle and to predict future changes in coastal systems and the complex biogeochemical impacts of these changes, including coastal ocean acidification.

An important question regarding estimates of $\mathrm{CO}_{2}$ fluxes in the ocean is how episodic events such as storms affect surface $p \mathrm{CO}_{2}$ and air-sea $\mathrm{CO}_{2}$ exchange. The effects of such events have not been well quantified in estimates of $\mathrm{CO}_{2}$ fluxes. In addition to their possible effect on $\mathrm{CO}_{2}$ fluxes, storms can potentially modify carbon biogeochemistry. For example, nutrients upwelled during storms may trigger phytoplankton blooms, altering the Biological Carbon Pump, a process that has not been well assessed on regional and global scales. Understanding the influence of storms on marine carbon biogechemistry is important to better constrain oceanic $\mathrm{CO}_{2}$ fluxes and to predict future changes in these fluxes, given that storm intensity may increase under climate change (Intergovernmental Panel on Climate Change, IPCC, 2013).

Evidence of the impact of storms on $\mathrm{CO}_{2}$ fluxes at the ocean surface has come from a number of studies. Based on shipboard observations made before and after the passage of hurricanes, Bates et al. (1998) showed that hurricanes increased the summertime $\mathrm{CO}_{2}$ efflux by nearly 55\% in the Sargasso Sea. Hood et al. (2001) observed a sharp decrease in surface seawater temperature (SST), as well as increases in $p \mathrm{CO}_{2}$ and nitrate concentrations, during a storm with wind speeds reaching 16-17 $\mathrm{m} \mathrm{s}^{-1}$. The $\mathrm{CO}_{2}$ flux during the storm doubled due to the elevated wind speed. Nemoto et al. (2009) found that three typhoons accounted for $60 \%$ of the summertime efflux of $\mathrm{CO}_{2}$ in the western subtropical North Pacific. Surface $\mathrm{pCO}_{2}$ was likely impacted by vertical turbulent mixing and upwelling resulting from the typhoons. Evidence that episodic events, such as typhoons, can have large effects on air-sea $\mathrm{CO}_{2}$ exchange has also been reported by Huang and Imberger (2010) and Sun et al. (2014). However, with a few exceptions, most previous studies were based on short-term observations (days to weeks) around typhoon periods, or on numerical simulation (Koch et al., 2009). As such, understanding of the effects of typhoons on $\mathrm{pCO}_{2}$ and $\mathrm{CO}_{2}$ fluxes over monthly to seasonal scales and beyond is presently limited. Long-term (encompassing a number of typhoons as well as quiescent between typhoons) and high-resolution time series $p \mathrm{CO}_{2}$ measurements, along with other relevant observations, are key to assess the impact of typhoons on $\mathrm{CO}_{2}$ fluxes over these longer scales. In addition, more dedicated studies are necessary to improve understanding of the mechanisms controlling surface $p \mathrm{CO}_{2}$ and impacting $\mathrm{CO}_{2}$ fluxes during storms. Such knowledge is key to establishing mechanistic models to evaluate storm effects on $\mathrm{pCO}_{2}$ and $\mathrm{CO}_{2}$ fluxes at the ocean surface.

With a total area of approximately $2.5 \times 10^{-6} \mathrm{~km}^{2}$, the South China Sea (SCS) is the largest tropical marginal sea in the western Pacific Ocean. Observations of surface $p \mathrm{CO}_{2}$ in the SCS show spatiotemporal variability in the range of 280 to $470 \mu \mathrm{atm}$ and suggest that the SCS as a whole serves as a weak to moderate source of $\mathrm{CO}_{2}$ to the atmosphere $\left(3.1 \pm 1.7 \mathrm{mmol} \mathrm{m}^{-2}\right.$ day $^{-1}$ ) (C. T. A. Chen et al., 2006; Dai et al., 2013; Zhai et al., 2005, 2013). Zhai et al. (2013) found that the northern SCS also served as a weak $\mathrm{CO}_{2}$ source with an annual air-sea $\mathrm{CO}_{2}$ flux of $1.3 \pm 1.2 \mathrm{mmol} \mathrm{m}^{-2}$ day $^{-1}$. However, earlier studies based on time series observations at the South-East Asian Time Series Study station (SEATS, $18^{\circ} 15^{\prime} \mathrm{N}, 115^{\circ} 35^{\prime} \mathrm{E}$ ) found that the northern SCS was a weak $\mathrm{CO}_{2}$ sink, removing $0.05-0.5 \mathrm{mmol} \mathrm{m}^{-2}$ day ${ }^{-1}$ from the atmosphere (Chou et al., 2005; Tseng et al., 2007). Since these studies are all several years in duration, the discrepancy suggests interannual variability of the $\mathrm{CO}_{2}$ flux in the northern SCS.

On a seasonal scale, the study of Zhai et al. (2013) showed that offshore surface water of the northern SCS releases $\mathrm{CO}_{2}$ to the atmosphere in spring $\left(1.7 \pm 0.8 \mathrm{mmol} \mathrm{m}^{-2}\right.$ day ${ }^{-1}$, surface $\mathrm{CCO}_{2}$ ranging from 363 to $444 \mu \mathrm{atm})$, becomes a stronger $\mathrm{CO}_{2}$ source in summer $\left(3.2 \pm 0.3 \mathrm{mmol} \mathrm{m}^{-2}\right.$ day ${ }^{-1}, p \mathrm{CO}_{2}$ from 353 to $421 \mu \mathrm{atm})$, and has air-sea $\mathrm{CO}_{2}$ exchanges that are nearly in equilibrium in autumn $\left(1.0 \pm 1.8 \mathrm{mmol} \mathrm{m}^{-2}\right.$ day $^{-1}, p \mathrm{CO}_{2}$ from 345 to 411$)$ and winter $\left(-0.9 \pm 1.9 \mathrm{mmol} \mathrm{m}^{-2}\right.$ day $^{-1}, p \mathrm{CO}_{2}$ from 324 to $\left.398 \mu \mathrm{atm}\right)$. In general, SST is the major factor controlling the seasonal variation of surface $p \mathrm{CO}_{2}$ in offshore areas, while biological effects seem to be secondary (Tseng et al., 2007; Zhai et al., 2005, 2013). On a shorter time scale, surface seawater $\mathrm{PCO}_{2}$ in these offshore waters shows a small diel change, on the order of $10 \mu \mathrm{atm}$ (Dai et al., 2009).

Due to a relatively stable and deep mixed-layer depth $(\sim 44 \mathrm{~m})$, vertical mixing has a limited effect on surface seawater $\mathrm{PCO}_{2}$ in the offshore SCS region (Dai et al., 2009). The northern SCS is also occasionally influenced by an intrusion of the Kuroshio Current via the Luzon Strait (C. T. A. Chen et al., 2001; Dai et al., 2013; 


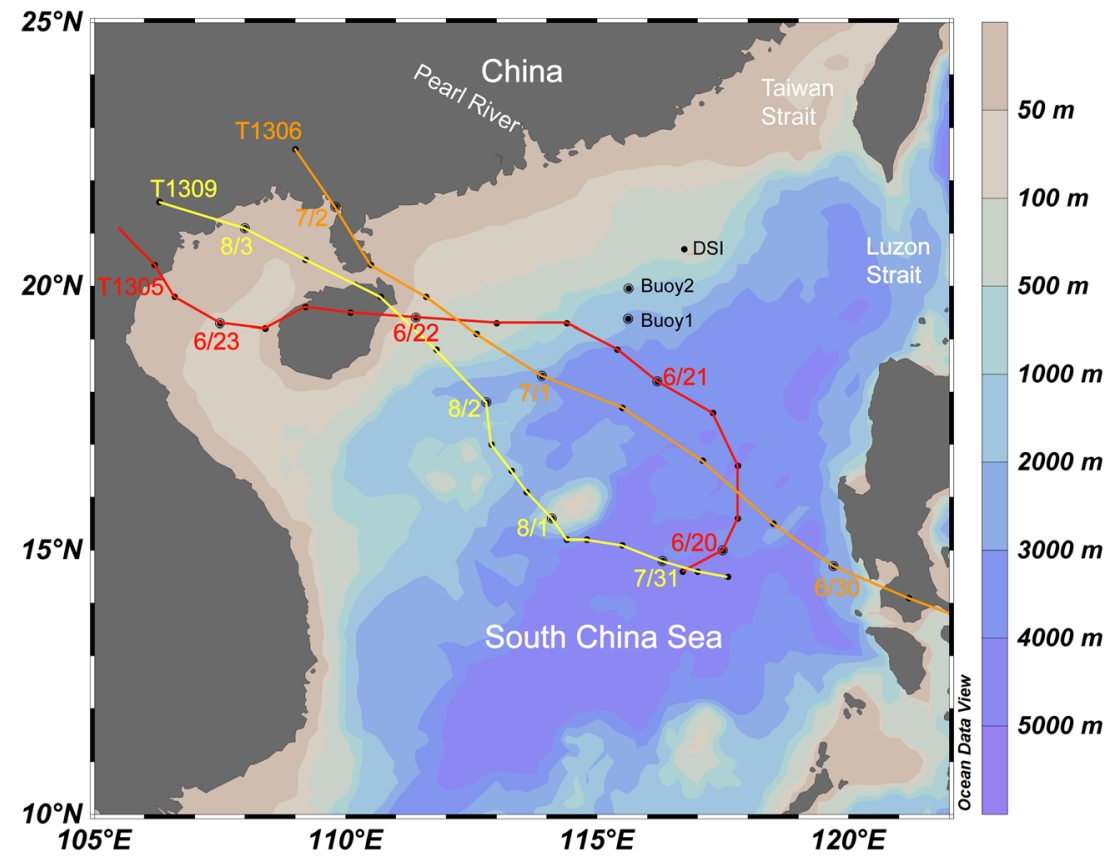

Figure 1. The northern South China Sea and vicinity with the tracks of three major typhoons in 2013. The locations of two buoy sites are marked as black dots. Colored lines represent the tracks of the three typhoons (T1305, T1306, and T1309). Dots along the track lines indicates a typhoon's location every $6 \mathrm{hr}$. DSI denotes Dongsha Island where atmospheric $x \mathrm{CO}_{2}$ was measured. Water depth is indicated by the color bar on the right. Map was produced with Ocean Data View software (https://odv.awi.de).

Du et al., 2013), which can generate mesoscale cyclonic eddies in the northeast monsoon season (Sheu et al., 2010). This process may pump water enriched in nutrients and $\mathrm{CO}_{2}$ from the depths to the surface, causing phytoplankton blooms (He et al., 2016; Shang et al., 2012).

In the nearshore region of the northern SCS, the air-sea $\mathrm{CO}_{2}$ exchange is small (i.e., near equilibrium) in spring $\left(0.4 \pm 1.6 \mathrm{mmol} \mathrm{m}{ }^{-2}\right.$ day $\left.^{-1}\right)$, summer $\left(-0.6 \pm 1.1 \mathrm{mmol} \mathrm{m}^{-2}\right.$ day $\left.^{-1}\right)$, and autumn $\left(0.2 \pm 1.9 \mathrm{mmol} \mathrm{m}^{-2}\right.$ day $\left.^{-1}\right)$ (Zhai et al., 2013). However, the region is a moderate $\mathrm{CO}_{2}$ sink in winter $\left(-4.8 \pm 2.6 \mathrm{mmol} \mathrm{m}{ }^{-2}\right.$ day $\left.^{-1}\right)$. As such, the annual air-sea $\mathrm{CO}_{2}$ flux is close to zero $\left(-1.2 \pm 1.8 \mathrm{mmol} \mathrm{m}^{-2}\right.$ day $^{-1}$ ) (Zhai et al., 2013). In addition to SST, other factors can impose high variability on surface $p \mathrm{CO}_{2}$ distribution in the nearshore region. The Pearl River plume in flooding seasons and seasonal upwelling along the southern China coast can have profound impacts on nearshore biogeochemical processes in the northern SCS (Bai et al., 2015). Each of these processes contributes significant inputs of nutrients to the coastal waters, inducing substantial drawdown of surface $p \mathrm{CO}_{2}$ through enhanced primary productivity (Cao et al., 2011; Dai et al., 2008).

To the best of our knowledge, no studies have investigated the effects of typhoons and other episodic events on surface $p \mathrm{CO}_{2}$ and air-sea $\mathrm{CO}_{2}$ flux in the northern SCS. Using extended in situ time series measurements in the SCS, this study explicitly examines and evaluates the effects of the passage of typhoons on surface seawater $p \mathrm{CO}_{2}$ and air-sea $\mathrm{CO}_{2}$ flux. We focus on characterizing and evaluating how biogeochemical and physical processes, such as cooling, mixing, and biological activity triggered by typhoons, impact surface $p \mathrm{CO}_{2}$, and $\mathrm{CO}_{2}$ flux, thus improving our understanding of the impact of typhoons on carbon biogeochemistry. We also assess the impact of typhoons on overall $\mathrm{CO}_{2}$ flux in the northern SCS during the last decade. The results provide insights on the factors controlling $\mathrm{CO}_{2}$ flux at the study site. We compare these results with findings from other regions in order to examine the similarities and differences in the tropical storm effects across sites. 


\section{Materials and Methods}

\subsection{Study Site}

The northern SCS is bordered by the mainland of China to the north and by the deep SCS basin to the south (Figure 1). It has a wide shelf extending 150 to $300 \mathrm{~km}$ offshore. The shelf system receives freshwater influx mainly from the Pearl River, which is the thirteenth among world rivers when ranked by discharge $\left(3.26 \times 10^{11} \mathrm{~m}^{3}\right.$ year $\left.^{-1}\right)$, with $80 \%$ of this influx occurring in the wet season from April to September (Guo et al., 2008; Su, 2004). The climate in the northern SCS is dominated by the Asian monsoon. The rain-bearing southwest monsoon lasts from June to September, while the northeast monsoon, typically characterized by higher wind speed, prevails from November to March, with a transition period from March to June (Han, 1998). Coastal upwelling often occurs in summer, driven by the prevailing southwest monsoon (Han \& Ma, 1988). The northern SCS slope area is typically oligotrophic (Wong et al., 2007) and low in productivity (Y. L. L. Chen \& Chen, 2006). However, phytoplankton productivity on both the shelf and slope in the northern SCS can be enhanced by the Pearl River plume and mesoscale eddies (He et al., 2016). The SCS experiences frequent typhoons, on average of more than seven annually, triggering sea surface cooling and phytoplankton blooms due to mixing and upwelling (Chang et al., 2008; C. T. A. Chen et al., 2003; Lin et al., 2003; Zhao et al., 2008).

\subsection{Measurements}

Surface water $p \mathrm{CO}_{2}$ was measured hourly using a SAMI-CO $\mathrm{C}_{2}$ sensor (Sunburst Inc., Missoula, MT, USA) mounted on a buoy moored in the northern SCS over 94 days in 2013 (Figure 1). The buoy was first deployed at $115^{\circ} 37^{\prime} 18^{\prime \prime} \mathrm{E}, 1^{\circ} 22^{\prime} 55^{\prime \prime} \mathrm{N}$ (Buoy 1 in Figure 1, water depth 2,610 m) from 8 May through 28 June 2013 . It was then serviced and redeployed at a nearby site $\left(115^{\circ} 37^{\prime} 35^{\prime \prime} \mathrm{E}, 19^{\circ} 57^{\prime} 11^{\prime \prime} \mathrm{N}\right.$, Buoy 2 in Figure 1, water depth $1,470 \mathrm{~m}$ ) from 28 June through 10 August 2013. The buoy sites, separated by $64 \mathrm{~km}$, were near the slope of the northern SCS (Figure 1). The nominal measurement range of the SAMI- $\mathrm{CO}_{2}$ sensor is between 150 and $700 \mu \mathrm{atm}$, with a manufacturer's reported accuracy of about $\pm 1 \mu \mathrm{atm}$. Before deployment, the sensor was calibrated in the laboratory against a flow-through $p \mathrm{CO}_{2}$ system (General Oceanics, Model G8050). The two systems were found to be in good agreement with a mean difference of $3.1 \pm 2.5 \mu \mathrm{atm}(n=9)$. The SAMI- $\mathrm{CO}_{2}$ sensor was located below the sea surface at $\sim 1 \mathrm{~m}$ in depth and was covered with copper mesh.

Wind speed and SST were obtained hourly from the meteorological sensors on the buoy. All buoy data were sent through iridium satellite to the laboratory at the Second Institute of Oceanography, Hongzhou, China, in real time. All data are reported in local time, as this is useful for discussion of effects of biological activities. During the study period, local sunrise and sunset times at the buoy site were $\sim 6$ a.m. and $\sim 7$ p.m., respectively. The typhoon track data used in this paper (Figure 1) were obtained from the U.S. Joint Typhoon Warning Centre (JTWC, http://www.usno.navy.mil/JTWC/). The data include the location and intensity of the typhoon centers at 6-hr intervals. Atmospheric $\mathrm{CO}_{2}$ mole fraction (in dry air, $x \mathrm{CO}_{2}{ }^{\text {air }}$ ) was measured at the Dongsha Island (DSI) monitoring site (https://www.esrl.noaa.gov/gmd/dv/data/index.php), located in the northern SCS at $116^{\circ} 43^{\prime} 47^{\prime \prime} \mathrm{E}, 20^{\circ} 41^{\prime} 57^{\prime \prime} \mathrm{N}$, about $200 \mathrm{~km}$ northeast of the buoy sites (Figure 1). $x \mathrm{CO}_{2}{ }^{\text {air }}$ was measured weekly from May to August 2013. To estimate air-sea $\mathrm{CO}_{2}$ flux, atmospheric $p \mathrm{CO}_{2}$ $\left(p \mathrm{CO}_{2}{ }^{\text {air }}\right)$ was calculated from $x \mathrm{CO}_{2}{ }^{\text {air }}$, SST and salinity.

\subsection{Air-Sea $\mathrm{CO}_{2}$ Flux}

Air-sea $\mathrm{CO}_{2}$ flux $(F)$ was calculated using the gas transfer velocity $(k)$, the $p \mathrm{CO}_{2}$ gradient between sea surface $\left(p \mathrm{CO}_{2}{ }^{\text {sea }}\right)$ and overlying air $\left(\mathrm{CO}_{2}{ }^{\text {air }}\right)$ as follows:

$$
F=k \times \mathrm{K}_{\mathrm{H}} \times\left(\mathrm{COO}_{2}{ }^{\text {sea }}-p \mathrm{CO}_{2}{ }^{\text {air }}\right)
$$

where $\mathrm{K}_{\mathrm{H}}$ is the solubility of $\mathrm{CO}_{2}$ in seawater (Weiss, 1974). Positive $F$ corresponds to a flux from ocean to atmosphere, meaning the ocean is an air-sea $\mathrm{CO}_{2}$ source to the atmosphere. In this study, we used four published $\mathrm{k}$ parameterizations based on wind speed at $10 \mathrm{~m}$ above sea surface $\left(U_{10}\right)$ to calculate fluxes:

$$
k=0.31 \times U_{10}^{2} \times\left(S_{c} / 660\right)^{-0.5}
$$

(Wanninkhof, 1992) 


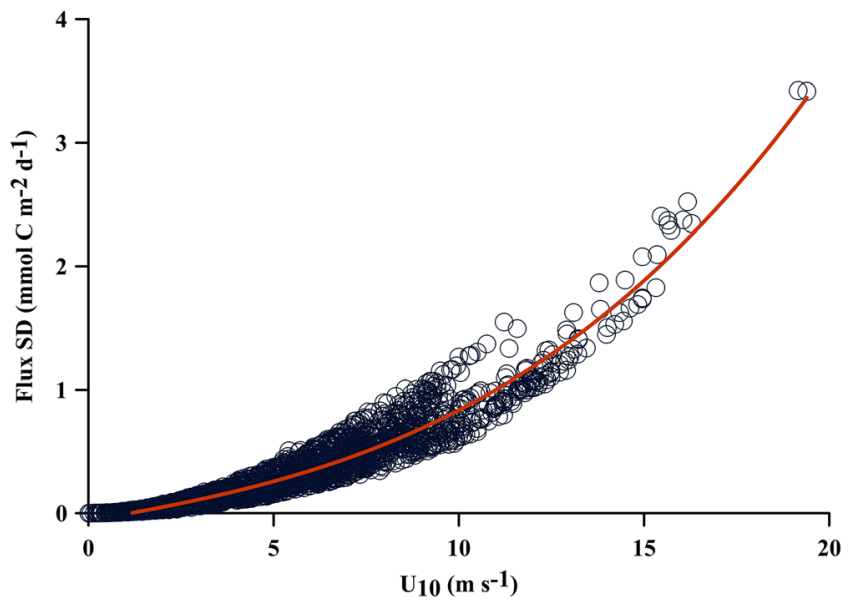

Figure 2. Standard deviation (SD) of calculated mean $\mathrm{CO}_{2}$ fluxes based on four different $k$ parameterizations (see text) as a function of $U_{10}$. Red line is regression curve.

$$
k=0.266 \times U_{10}^{2} \times\left(S_{c} / 660\right)-{ }^{0.5}
$$

(Ho et al., 2006)

$$
k=0.27 \times U_{10}^{2} \times\left(S_{c} / 660\right)^{-0.5}
$$

(Sweeney et al., 2007)

$$
k=0.251 \times U_{10}^{2} \times\left(S_{c} / 660\right)^{-0.5}
$$

(Wanninkhof, 2014) where $S_{c}$ is the Schmidt number for $\mathrm{CO}_{2}$ in seawater. These equations have been frequently used in marine $\mathrm{CO}_{2}$ studies. Equations 2 and 4 were also used to estimate air-sea $\mathrm{CO}_{2}$ flux in the SCS in previous study (Zhai et al., 2013). Equation 5 is an update on the widely used method by Wanninkhof (1992). Herein, we report mean flux values calculated from the above four equations with one standard deviation (SD). The rational is that the averaged $k$ represents the largest number of relevant independent observations used to derived these equations and thus better reflects the real uncertainty of $k$ (as compared with the k produced by a single parameterization).

In this study, an AIRMAR wind sensor (Model 150WX) was deployed on the mooring at $\sim 3 \mathrm{~m}$ above the sea surface. Wind speed was converted to $U_{10}$ using the equation derived by Large and Pond (1981):

$$
U_{10}=U_{Z} /\left(1+\frac{\sqrt{C d_{10}}}{0.4} \times \ln \left(\frac{Z}{10}\right)\right)
$$

where $Z$ is the height $(\mathrm{m})$ above sea surface ( $3 \mathrm{~m}$ in this study), $U_{Z}$ is wind speed $\left(\mathrm{m} \mathrm{s}^{-1}\right.$ ) measured at $Z$, $C d_{10}$ is the drag coefficient (0.0011), and 0.4 is von Karman's constant. $U_{10}$ was based on gust wind speed.

To evaluate effects of typhoons on surface $\mathrm{pCO}_{2}$ and $\mathrm{CO}_{2}$ flux, the typhoon effect period (TEP) was defined as the period that starts when $U_{10}$ was $30 \%$ higher than the mean value in the previous $24 \mathrm{hr}$ and ends when $U_{10}$ returned to its starting value before the typhoon's passage. This definition captured the periods when the $U_{10}$ was elevated by typhoons, though it is somewhat arbitrary as there is no established definition for TEP.

\subsection{Uncertainty of Air-Sea $\mathrm{CO}_{2}$ Flux Calculation}

The major uncertainty of the air-sea $\mathrm{CO}_{2}$ flux calculation is due to $k$ parameterization, which has an estimated uncertainty of $20 \%$ when $U_{10}>3 \mathrm{~m} / \mathrm{s}$ (Wanninkhof, 2014). At low winds, nonwind effects such as chemical enhancement and thermal boundary layer processes influence gas transfer, and the quadratic relationship will underestimate gas transfer velocity (Wanninkhof, 2014). In this study, we evaluated the variability of $\mathrm{CO}_{2}$ flux by using different $k$ parameterizations (Equations $2-5$ ). When $U_{10}<6 \mathrm{~m} \mathrm{~s}^{-1}$, the condition during most of the nontyphoon periods (Figure 2), the SD of mean $\mathrm{CO}_{2}$ flux calculated from the four equations ranged from 0 to $0.5 \mathrm{mmol} \mathrm{m}^{-2}$ day $^{-1}$ with a mean of $0.2 \mathrm{mmol} \mathrm{m}^{-2} \mathrm{day}^{-1}$. The SD increased to $0.5-3.4$ (with a mean of 1.0) $\mathrm{mmol} \mathrm{m}^{-2}$ day $^{-1}$ when $U_{10}>9 \mathrm{~m} \mathrm{~s}^{-1}$, which was the predominant condition during TEPs. The maximum SD of $3.4 \mathrm{mmol} \mathrm{m}^{-2}$ day ${ }^{-1}$ occurred when $U_{10}$ reached $19.4 \mathrm{~m} \mathrm{~s}^{-1}$, corresponding to an air-sea $\mathrm{CO}_{2}$ flux of $41.7 \mathrm{mmol} \mathrm{m}{ }^{-2}$ day $^{-1}$ (Figure 2). The relative $\mathrm{SD}$ of $\mathrm{CO}_{2}$ fluxes across all wind speedswas $\sim 8 \%$. These uncertainties do not affect our interpretation of the effects of typhoons on $\mathrm{CO}_{2}$ flux, as the cumulative $\mathrm{CO}_{2}$ flux during typhoons accounts for $22 \%$ of $\mathrm{CO}_{2}$ fluxes during the study period (see section 3.3) or $23-56 \%$ of the annual $\mathrm{CO}_{2}$ flux during 2008-2018 (see section 3.4).

Another uncertainty may result from using the weekly measurement of $x \mathrm{CO}_{2}{ }^{\text {air }}$, while the $p \mathrm{CO}_{2}$ data have higher (hourly) resolution. We used linear interpolation to convert the weekly $x \mathrm{CO}_{2}{ }^{\text {air }}$ data to hourly values for the flux calculation. We estimated the potential uncertainty of using weekly $x \mathrm{CO}_{2}{ }^{\text {air }}$ data by examining

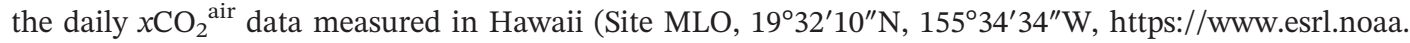
gov/gmd/dv/data/index.php). Daily $x \mathrm{CO}_{2}{ }^{\text {air }}$ at MLO ranged between 395.27 and 400.39 ppm during the period of 8 May through 10 August 2013 when our measurements took place. The differences between this daily 


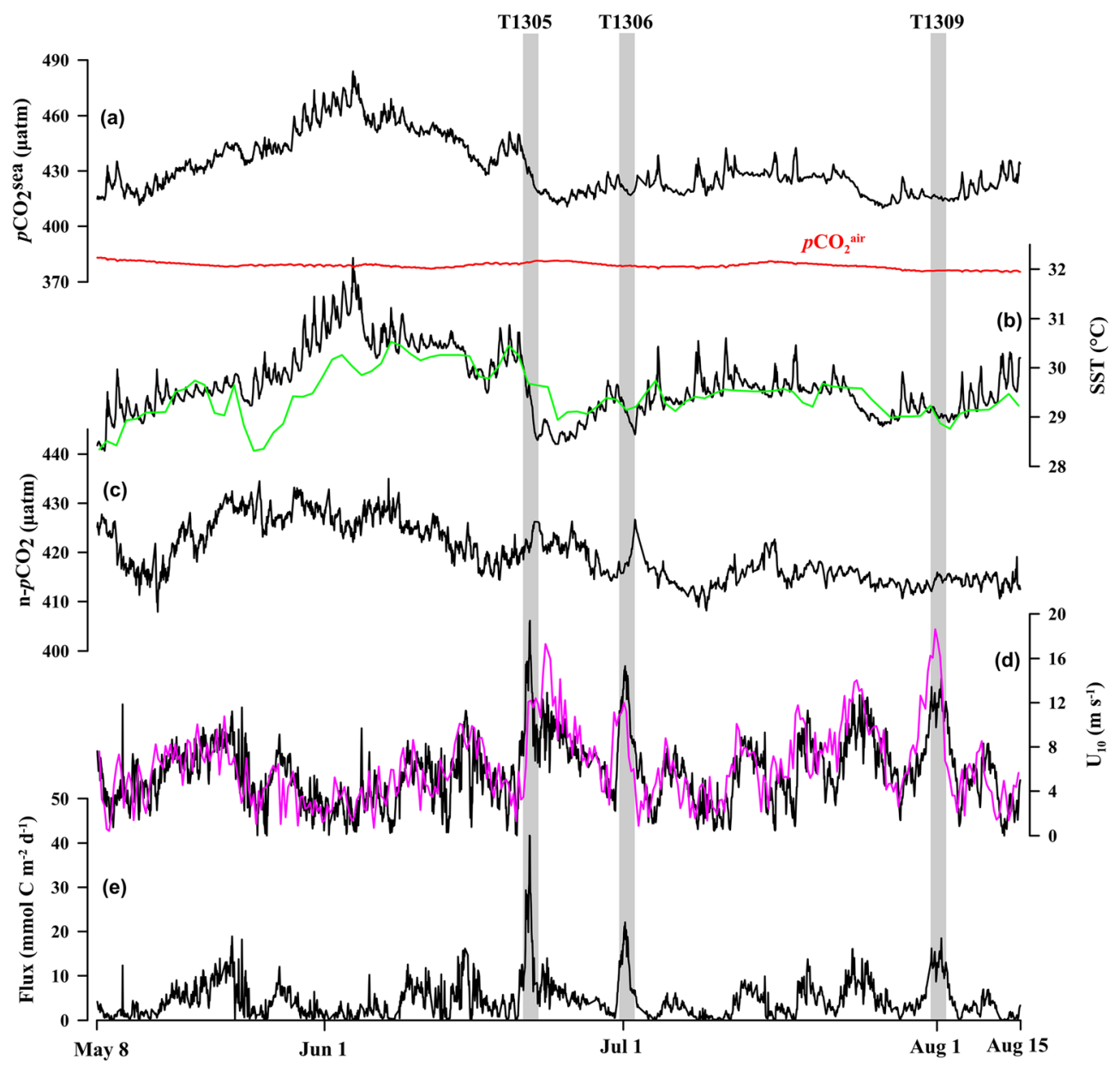

Figure 3. Variations of surface $p \mathrm{CO}_{2}$ (a), SST (b), $n-p \mathrm{CO}_{2}$ (c), $U_{10}$ (d), and $\mathrm{CO}_{2}$ flux (e) in the northern SCS from 8 May to 10 August in 2013. $p \mathrm{CO}_{2}$ (a), SST (b), and $U_{10}$ (d) were measured in situ hourly. Gray areas represent the periods of three typhoons passing by. Green line represents SST data from ERSL. Purple line represents $U_{10}$ data from NCEP.

$x \mathrm{CO}_{2}{ }^{\text {air }}$ series and a daily series determined by taking weekly $x \mathrm{CO}_{2}{ }^{\text {air }}$ points and interpolating them to hourly values varied from -0.86 to $0.74 \mathrm{ppm}$. Such differences are only $\sim 0.2 \%$ of the mean $x \mathrm{CO}_{2}{ }^{\text {air }}$ (398.21 ppm) during the period. At the mean wind speed and mean $p \mathrm{CO}_{2}$ observed in this study, this translates to a $\mathrm{CO}_{2}$ flux uncertainty of $\sim 0.06 \mathrm{mmol} \mathrm{C} \mathrm{m}^{-2}$ day $^{-1}$ or $\sim 1.5 \%$, which is insignificant in our flux calculations.

\section{Results and Discussion}

\subsection{Surface Variability}

Hourly measured sea surface $p \mathrm{CO}_{2}$ showed high variability over multiple time scales in the northern SCS from early May through August 2013 (Figure 3a). $p \mathrm{CO}_{2}$ generally trended closely with SST (Figure 3b), following a significant relationship of $p \mathrm{CO}_{2}=(369 \pm 19 \mu \mathrm{atm}) \times e^{0.0423(S S T-26)}\left(n=2,049, r^{2}=0.876\right)$, where 26 is the annual average SST of the offshore water in ${ }^{\circ} \mathrm{C}$ (Zhai et al., 2005). This is nearly identical to a SST- $p \mathrm{CO}_{2}$ relationship derived from underway observations in the northern SCS by Zhai et al. (2005). From early May through early June, $p \mathrm{CO}_{2}$ gradually increased with rising water temperature, primarily the result of increased solar heating. Subsequently, $p \mathrm{CO}_{2}$ exhibited a decreasing trend until late June (Figure 3a) and showed less variation thereafter. The maximum $p \mathrm{CO}_{2}$ value of $484 \mu \mathrm{atm}$ occurred on 3 June, which corresponded to a SST maximum of $32.23^{\circ} \mathrm{C}$. The minimum $p \mathrm{CO}_{2}$ of $410 \mu \mathrm{atm}$ was observed on 27 July, while the minimum SST value of $28.31^{\circ} \mathrm{C}$ occurred on 9 May. The mean $( \pm \mathrm{SD}) p \mathrm{pO}_{2}$ was $432 \pm 15 \mu \mathrm{atm}(n=2,049)$ during the study period. 
$p \mathrm{CO}_{2}{ }^{\text {air }}$ had a mean value of $379 \mu \mathrm{atm}$ from May through August with little variation $( \pm 2 \mu \mathrm{atm})$ (Figure $\left.3 \mathrm{a}\right)$. Air-sea $p \mathrm{CO}_{2}$ difference, $\Delta p \mathrm{CO}_{2}$, defined as $p \mathrm{CO}_{2}{ }^{\text {sea }}-p \mathrm{CO}_{2}{ }^{\text {air }}$, ranged from 29 to $106 \mu$ atm with a mean of $53 \pm 16 \mu \mathrm{atm}$. The region was a $\mathrm{CO}_{2}$ source to the atmosphere during the entire study period.

SST showed limited variation, with a mean of $29.66 \pm 0.66^{\circ} \mathrm{C}(n=2,216)$ during the study period (Figure 3b). To control for the effect of temperature, $p \mathrm{CO}_{2}$ was normalized to $T=29^{\circ} \mathrm{C}$ (close to mean SST) as $n-p \mathrm{CO}_{2}$, which was confined within a narrow range of $420 \pm 6 \mu \mathrm{atm}(n=2,049)$ from May through August (Figure 3c), even though the study period covered a major portion of the production season. Overall, surface variability of $\mathrm{pCO}_{2}$ measured at the buoy site is representative of an oligotrophic nonupwelling system, where the thermal effect primarily controls surface $p \mathrm{CO}_{2}$ and the biological effect is limited. Such a condition resulted in the ocean being a net weak $\mathrm{CO}_{2}$ source during the study period. The study site thus bears the characteristics of a tropical/subtropical shelf region in terms of air-sea $\mathrm{CO}_{2}$ fluxes (Cai et al., 2006).

During the study period of 8 May to 10 August 2013, five typhoons passed through the northern SCS. Among these typhoons, three (T1305-Bebinca, T1306-Rumbia, and T1309-Jebi) passed south of the buoy sites at a nearest distance from 69 to $382 \mathrm{~km}$ (Figure 1). They had appreciable effects on $U_{10}$ at buoy sites (Figure 3d). The effects of the other two typhoons were relatively small and will not be discussed. Rapid increase of $U_{10}$ and decrease of $\mathrm{pCO}_{2}$ and SST were observed during the three TEPs (gray area in Figure 3). This suggests that typhoons may have a large effect on SST, $U_{10}$ and $p \mathrm{CO}_{2}$ and thus on air-sea $\mathrm{CO}_{2}$ flux.

$U_{10}$ measured at times other than the typhoon events was generally below $8 \mathrm{~m} \mathrm{~s}^{-1}$ with an average of $5.3 \pm 2.5 \mathrm{~m} \mathrm{~s}^{-1}$. During each typhoon event, $U_{10}$ at the buoy site sharply increased and reached a maximum value as high as $19.4 \mathrm{~m} \mathrm{~s}^{-1}$ (Figure 3d). $U_{10}$ decreased to a normal range within 1 to 2 days after each typhoon event. The air-sea $\mathrm{CO}_{2}$ flux was mostly below $10 \mathrm{mmol} \mathrm{C} \mathrm{m}^{-2}$ day ${ }^{-1}$ outside TEPs (Figure 3e). The mean $\mathrm{CO}_{2}$ flux during the entire study period was $4.6 \pm 4.2(n=2,020) \mathrm{mmol} \mathrm{C} \mathrm{m}^{-2}$ day $^{-1}$. However, the mean flux during TEPs was $12.3 \pm 6.7(n=166)$, with the highest flux of $41.7 \pm 3.4 \mathrm{mmol} \mathrm{C} \mathrm{m}^{-2} \mathrm{day}^{-1}$ occurring during Typhoon T1305 (Figure 3e).

\subsection{Effects of Typhoons on $\mathrm{pCO}_{2}$}

The buoy data revealed significant variations in $\mathrm{pCO}_{2}$ at time scales ranging from hours to months. The most pronounced temporal changes in $\mathrm{pCO}_{2}$ were associated with the passage of typhoons. Three typhoons passed the area near the buoy from June to August 2013, all significantly impacting $p \mathrm{CO}_{2}$ and $\mathrm{CO}_{2}$ fluxes (Figures 1 and 3). The three typhoons affected $\mathrm{pCO}_{2}$ in similar and contrasting ways, which are detailed in the following sections.

\subsubsection{Typhoon Bebinca (T1305, 21-24 June 2013)}

Typhoon Bebinca (T1305) formed in the central SCS on 20 June and passed south of the buoy site on 21 June (Figure 1). The nearest distance between the typhoon center and the buoy site was $\sim 69 \mathrm{~km}$ (Table 1). On 1920 June, before the passage $\mathrm{T} 1305, U_{10}$ was low $\left(\% 3 \mathrm{C} \mathrm{m} \mathrm{s}^{-1}\right)$, and $p \mathrm{CO}_{2}$ and SST had clear diel cycles (Figure $4 \mathrm{a}$ ). The values of $\mathrm{pCO}_{2}$ and SST had an afternoon maximum occurring between 14:00 and 15:00 of $\sim 450 \mu \mathrm{atm}$ and $\sim 31^{\circ} \mathrm{C}$, respectively, and a morning minimum occurring between 7:00 and 9:00 of $\sim 437 \mu \mathrm{atm}$ and $\sim 30^{\circ} \mathrm{C}$, respectively. The surface heating and cooling were prominent over a diel cycle. The daily $\mathrm{pCO}_{2}$ cycle closely followed the daily temperature cycle (Figure 4a). After removing the temperature effect, $n-p \mathrm{CO}_{2}$ showed little diel variation before the TEP, indicating that temperature was indeed the major driver of surface $p \mathrm{CO}_{2}$ variations before Typhoon T1305. $U_{10}$ also had a diel cycle before the typhoon, with the minimum occurring between 8:00 and 9:00 and the maximum occurring around 0:00, and with a range of $0-6 \mathrm{~m} \mathrm{~s}^{-1}$ (Figure $4 \mathrm{~b}$ ).

The TEP of Typhoon T1305 started in the afternoon of 20 June (Figure 4a). During the TEP, $U_{10}$ increased from $5.9 \mathrm{~m} \mathrm{~s}^{-1}$ to a maximum of $19.4 \mathrm{~m} \mathrm{~s}^{-1}$ in $27 \mathrm{hr}$, while SST and $p \mathrm{CO}_{2}$ decreased by $\sim 1.2^{\circ} \mathrm{C}$ and $\sim 20 \mu$ atm simultaneously with minimal changes in $n-p \mathrm{CO}_{2}$ (Figure 4a). The typhoon thus had a pronounced cooling effect, which primarily caused the decrease of $p \mathrm{CO}_{2}$ (Koch et al., 2009). Thereafter, $U_{10}$ decreased from its maximum to about $8 \mathrm{~m} \mathrm{~s}^{-1}$ in $12 \mathrm{hr}$. During this period, SST and $p \mathrm{CO}_{2}$ continued to decrease, while $n-p \mathrm{CO}_{2}$ showed a slight increase of $\sim 5 \mu \mathrm{atm}$. Immediately after the passage of this typhoon, on 23 June, $U_{10}$ 
Table 1

Summary Information of Three Typhoons in the Study

\begin{tabular}{|c|c|c|c|c|c|c|c|c|}
\hline \multirow[b]{3}{*}{ Typhoon } & \multirow{3}{*}{$\begin{array}{l}\text { Date passing } \\
\text { through the SCS }\end{array}$} & \multicolumn{3}{|c|}{ Radius of maximum wind speed } & \multicolumn{3}{|c|}{ Wind speed } & \multirow{3}{*}{$\begin{array}{l}\text { The nearest distance } \\
\text { to the buoy }(\mathrm{km})\end{array}$} \\
\hline & & Min & Mean & Max & Min & Mean & $\operatorname{Max}$ & \\
\hline & & \multicolumn{3}{|c|}{$(\mathrm{km})$} & \multicolumn{3}{|c|}{$\left(\mathrm{m} \mathrm{s}^{-1}\right)$} & \\
\hline T1305 Bebinca & 20 Jun to 23 Jun & 83 & 90 & 93 & 10.3 & 13.8 & 18.0 & 69 \\
\hline T1306 Rumbia & 29 Jun to 2 Jul & 19 & 62 & 83 & 18.0 & 24.1 & 36.0 & 251 \\
\hline T1309 Jebi & $31 \mathrm{Jul}$ to $3 \mathrm{Aug}$ & 37 & 70 & 111 & 15.4 & 22.3 & 30.9 & 382 \\
\hline
\end{tabular}

Note. Radius of maximum wind speed is the distance between the typhoon center and the location of maximum wind.

still fluctuated around $9 \mathrm{~m} \mathrm{~s}^{-1}$, while $n-p \mathrm{CO}_{2}$ recovered to the pretyphoon value. Neither SST nor $p \mathrm{CO}_{2}$ recovered to the pretyphoon levels on 19 and 20 June (Figure $4 \mathrm{a}$ ).

Interestingly, the typhoon seemed to have a three-step effect (Figures $4 \mathrm{a}$ and $4 \mathrm{~b}$ ). The first step was mainly to lower the surface temperature, and thus surface $p \mathrm{CO}_{2}$, with limited changes in $n-p \mathrm{CO}_{2}$ (Figure $4 \mathrm{a}$ ). In the second step, surface temperature and $p \mathrm{CO}_{2}$ continued to decrease while $n-p \mathrm{CO}_{2}$ was elevated. Thereafter, in the third step, $n-p \mathrm{CO}_{2}$ decreased while temperature increased and in situ $p \mathrm{CO}_{2}$ changed little. The plausible mechanisms of these changes may be the following: (1) As the typhoon moved into the area of the buoy, it caused surface water cooling, which in turn caused surface $p \mathrm{CO}_{2}$ to decrease while $n-p \mathrm{CO}_{2}$ changed little. (2) In the second step, water with relatively high $\mathrm{CO}_{2}$ concentration was brought up from depth through vertical mixing and the surface water was continuous cooled. The cooling effect on $\mathrm{pCO}_{2}$ probably exceeded the effect of the mixing and caused a net decrease of $\mathrm{pCO}_{2}$. However, the vertical mixing seemed to elevate $n-p \mathrm{CO}_{2}$ in the second step (Figure 4a). (3) In the third step, $n-p \mathrm{CO}_{2}$ decreased, likely due to biological uptake stimulated by the nutrient supply from deep water. Meanwhile, $p \mathrm{CO}_{2}$ changed little as a result of the balance between SST increase and biological activity. Unfortunately, no chlorophyll or fluorescence measurements were acquired during the typhoon periods, and satellite data were not available during these periods due to cloud coverage. However, the above interpretation is consistent with the observations, and explanations, from similar studies in the North Pacific and North Atlantic (Hood et al., 2001; Nemoto et al., 2009).

After the passage of T1305, $p \mathrm{CO}_{2}$ was consistently more than $25 \mu \mathrm{atm}$ lower than pretyphoon values. This $p \mathrm{CO}_{2}$ decrease was accompanied by an SST decrease of $1.5^{\circ} \mathrm{C}$. By calculation, this cooling effect alone corresponds to a $p \mathrm{CO}_{2}$ decrease of $26 \mu \mathrm{atm}$, consistent with the observed $p \mathrm{CO}_{2}$ decrease seen before and after the typhoon.

\subsubsection{Typhoon Rumbia (T1306, 30 June to 3 July 2013)}

The second typhoon, Typhoon Rumbia (T1306), entered the SCS on 30 June. Its center passed south of the buoy at a nearest distance of $251 \mathrm{~km}$ (Table 1). Before the passage of T1306, $p \mathrm{CO}_{2}$ varied between 415 and $430 \mu \mathrm{atm}$ and SST ranged from 28.92 to $29.74^{\circ} \mathrm{C}$ (Figures $4 \mathrm{c}$ and $4 \mathrm{~d}$ ). The diel cycles of SST and $p \mathrm{CO}_{2}$ observed prior to $\mathrm{T} 1306$ were similar to those seen before $\mathrm{T} 1305$, while $n-p \mathrm{CO}_{2}$ again varied little (Figure 4c). This typhoon also produced a three-step effect in $p \mathrm{CO}_{2}$ during its TEP. First, $U_{10}$ started increasing in the middle of June 30 (Figure 4d). Within $17 \mathrm{hr}$ (first step), $p \mathrm{CO}_{2}$ and SST decreased by $9 \mu$ atm and $0.65^{\circ} \mathrm{C}$, respectively, while $n-p \mathrm{CO}_{2}$ showed little change (Figure $4 \mathrm{c}$ ). After $U_{10}$ reached its maximum value $\left(15.3 \mathrm{~m} \mathrm{~s}^{-1}\right)$ around 9:00 on 1 July (start of the second step), SST continued to decrease, while $n-p \mathrm{CO}_{2}$ started to increase. However, $p \mathrm{CO}_{2}$ changed little until early 2 July, after which it increased and reached $\sim 430 \mu$ atm in the latter part of 2 July. SST began to recover in the middle of 2 July. This pattern was similar to that observed during Typhoon T1305, when cooling seemed to play a major role in controlling surface $p \mathrm{CO}_{2}$ initially, and vertical mixing seemed to surpass the cooling effect later on. By 3 July, SST and $p \mathrm{CO}_{2}$ had recovered to their pretyphoon values. In the third step, $n-p \mathrm{CO}_{2}$ decreased by more than $10 \mu$ atm from 2 to 3 July, again probably an indication of elevated biological activity that seemed to be more prominent than that during Typhoon T1305.

3.2.3. Typhoon Jebi (T1309, 1-4 August 2013)

The effects of Typhoon T1309 were somewhat different from the previous two. On 30-31 July, before the passage of T1309, SST and $p \mathrm{CO}_{2}$ again covaried and followed a similar diel pattern (Figure 4e). However, as 

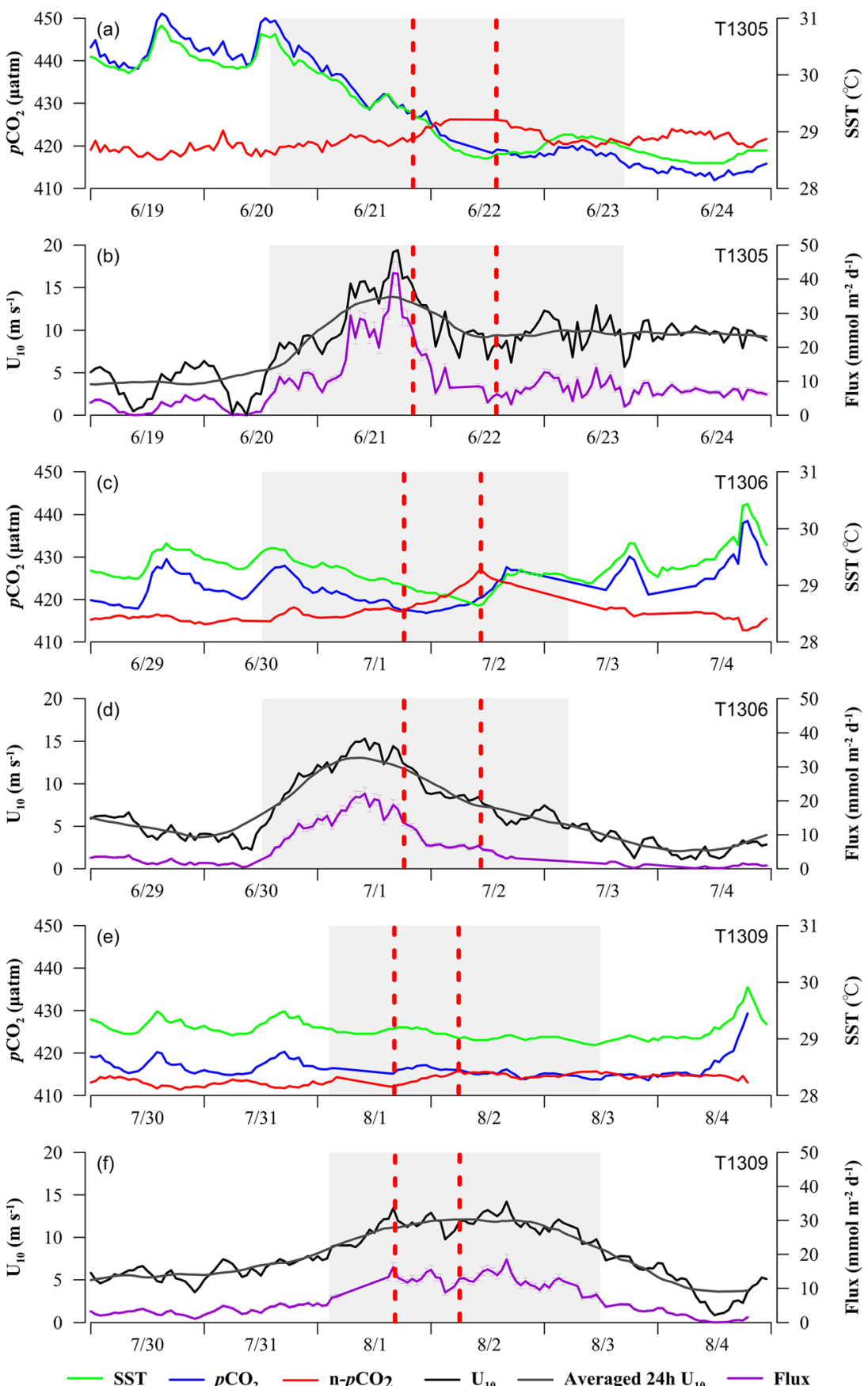

Figure 4. Variations of surface SST, $p \mathrm{CO}_{2}, n-p \mathrm{CO}_{2}, U_{10}$, and $\mathrm{CO}_{2}$ flux before, during and after three typhoons: Typhoon T1305 (a and b), Typhoon T1306 (c and d), and Typhoon T1309 (e and f). Gray shaded areas represent TEPs. Red dashed lines mark the approximate separation of the three steps during each TEP where different typhoon effects on $p \mathrm{CO}_{2}$ and $n-p \mathrm{CO}_{2}$ occurred (see text)

opposed to what was observed prior to the previous two typhoons, $n-p \mathrm{CO}_{2}$ also seemed to have a slight diel cycle before Typhoon T1309, with a $n-p \mathrm{CO}_{2}$ minimum at around 16:00 and a maximum around 05:00 (Figure 4e). This was opposite to the $p \mathrm{CO}_{2}$ diel pattern but was consistent with effects of biological activity in which net primary production drove $n-p \mathrm{CO}_{2}$ to low values during the day while net respiration drove $n-p \mathrm{CO}_{2}$ higher at night. The diel cycle of $p \mathrm{CO}_{2}$ includes combined effects of SST, biology, and other factors, such as mixing. Before the typhoon, SST was still the major driver of surface $p \mathrm{CO}_{2}$, as both 

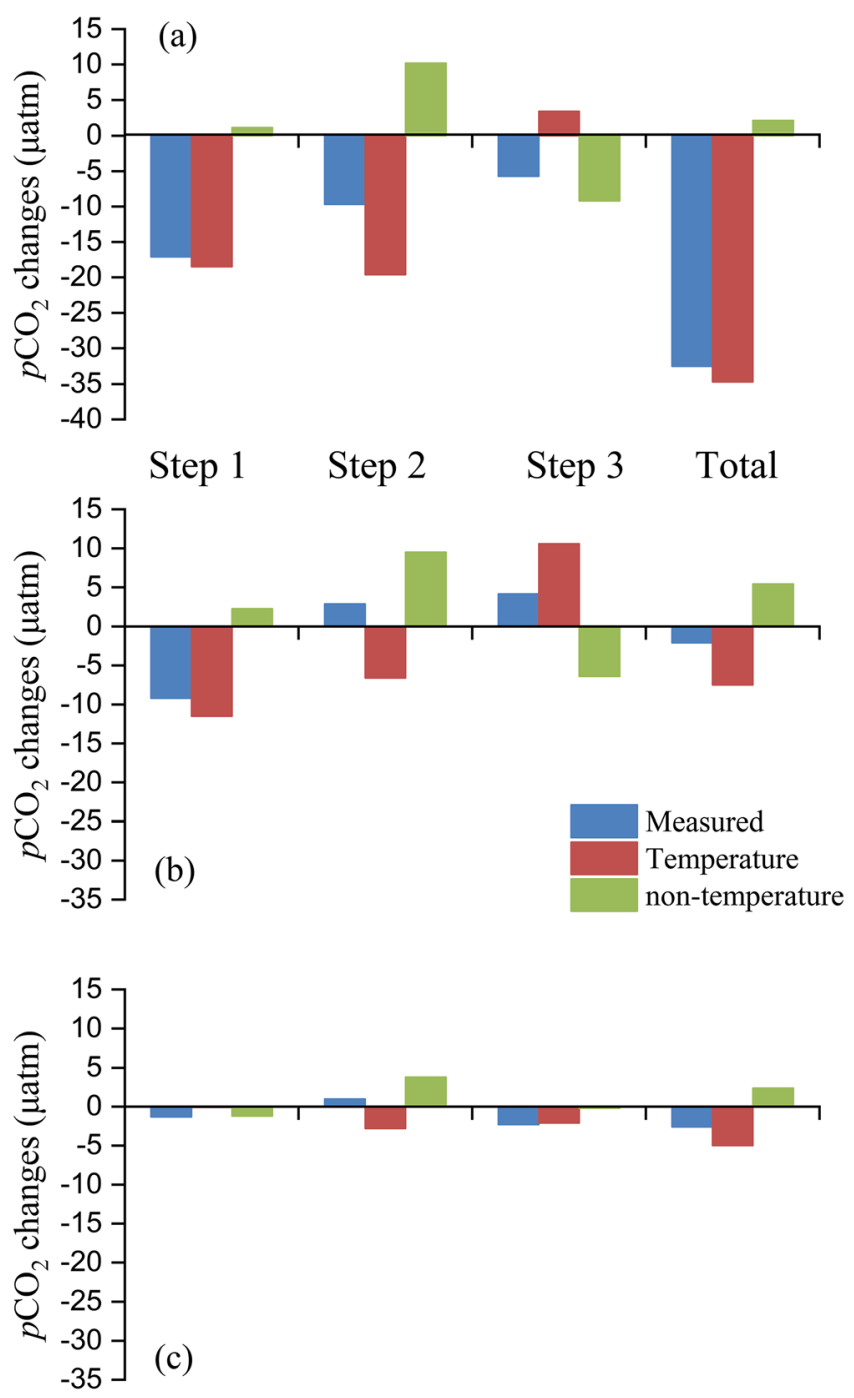

Figure 5. Contributions of temperature and nontemperature factors to surface $p \mathrm{CO}_{2}$ changes during Typhoons T1305 (a), T1306 (b), and T1309 (c). Each TEP was further divided into three steps as defined in Figure 4. Temperature effect was calculated from temperature changes between each step using temperature factor of $0.0423^{\circ} \mathrm{C}^{-1}$ (Takahashi et al., 1993). Nontemperature effect was calculated as the residuals between total change in $p \mathrm{CO}_{2}$ and change due to temperature effect. Total effect during each TEP was calculated as the sum of individual changes in three steps. strongly covaried (Figure $4 \mathrm{e}$ ). Starting on 1 August, $U_{10}$ increased over $14 \mathrm{hr}$ from $\sim 7 \mathrm{~m} \mathrm{~s}^{-1}$ to a maximum of $14.2 \mathrm{~m} \mathrm{~s}^{-1}$ due to the typhoon. In the next 3 days, SST and $p \mathrm{CO}_{2}$ showed little diel variation and their values slightly decreased by $\sim 0.29^{\circ} \mathrm{C}$ and $\sim 4 \mu \mathrm{atm}$, respectively. In the meantime, $n-p \mathrm{CO}_{2}$ increased by $\sim 4 \mu \mathrm{atm}$. There was no clear three-step effect produced by this typhoon. Because this typhoon passed no closer than $382 \mathrm{~km}$ from the buoy site, much farther than the closest approach of other two typhoons, the effects on SST and $p \mathrm{CO}_{2}$ were relatively small. On 4 August, the diel cycles of SST and $p \mathrm{CO}_{2}$ recovered but with a much larger range than before the storm.

\subsubsection{Assessments of Typhoon Effects on $\mathrm{pCO}_{2}$}

Even though the proposed three-step process is tentative, further assessments of the contributions of temperature and nontemperature factors on changes of surface $p \mathrm{CO}_{2}$ over TEPs may be helpful in supporting the three-step interpretation for Typhoons T1305 and T1306 (Figure 5). Even though there was not a clear three-step effect for Typhoon T1309 (Figure 4), we approximately categorized its three steps based on $n-p \mathrm{CO}_{2}$ for comparison: $n-p \mathrm{CO}_{2}$ had little change in the first step, and the second step started when $n-p \mathrm{CO}_{2}$ started to increase until the maximum, followed by the third step, which then concluded at the end of TEP.

For Typhoons T1305 and T1306, it is clear that in the first step decreasing temperature had a dominant effect on declining surface $p \mathrm{CO}_{2}$, while nontemperature factors (i.e., physical and biological factors) had a minor effect (Figure 5). In the second step, temperature still played an important role in changes in $p \mathrm{CO}_{2}$, but nontemperature factors, presumably vertical mixing (as no previous studies or data have suggested elevated biological activities during a cyclone), caused the $p \mathrm{CO}_{2}$ to increase significantly, with a magnitude similar to the temperature effect. The effect of these two factors counteracted each other, causing relatively small changes in $\mathrm{pCO}_{2}$. In the third step, temperature increase caused the increase of $p \mathrm{CO}_{2}$, while nontemperature factors, probably net biological uptake fueled by nutrient-rich water from depth, caused the decrease of $\mathrm{pCO}_{2}$. The net effect of temperature and biology in the third step caused a small change in $\mathrm{pCO}_{2}$. Enhanced biological production was also attributed to the decrease of $\mathrm{pCO}_{2}$ in the East China Sea and North Atlantic after typhoon passage (Hood et al., 2001; Nemoto et al., 2009). This study suggests, however, that surface $p \mathrm{CO}_{2}$ may not always decrease, depending on the balance of warming and enhanced primary production after typhoon passage. Overall, temperature was still likely the main factor controlling $\mathrm{pCO}_{2}$ for all typhoons, while nontemperature factors, that is, mixing and biology, might have accounted for a significant portion of $\mathrm{pCO}_{2}$ changes at times. It is also noted that vertical mixing and biology have opposite effects on surface $\mathrm{pCO}_{2}$, and thus, the net effect of the two might vary between typhoons (Figure 5).

The magnitude of the effects of these three typhoons on surface $p \mathrm{CO}_{2}$ is different (Figure 5). This is likely related to the distance between the typhoon track and the buoy sites, as well as the typhoon intensity. The maximum wind speed of T1305 was much lower than T1306 and T1309 (Table 1). But the radius of maximum wind speed of T1305 was larger than T1306 and T1309 (Table 1). The nearest distance between the typhoon track and the buoy site for T1305 was only $\sim 69 \mathrm{~km}$, much closer than the nearest distances of T1306 $(\sim 251 \mathrm{~km})$ and T1309 ( 382 km). Typhoon T1305 had the greatest influence on $p \mathrm{CO}_{2}$, followed by T1306 and T1309 (Figure 5). This indicates that the distance between the typhoon track and the buoy site was much more 

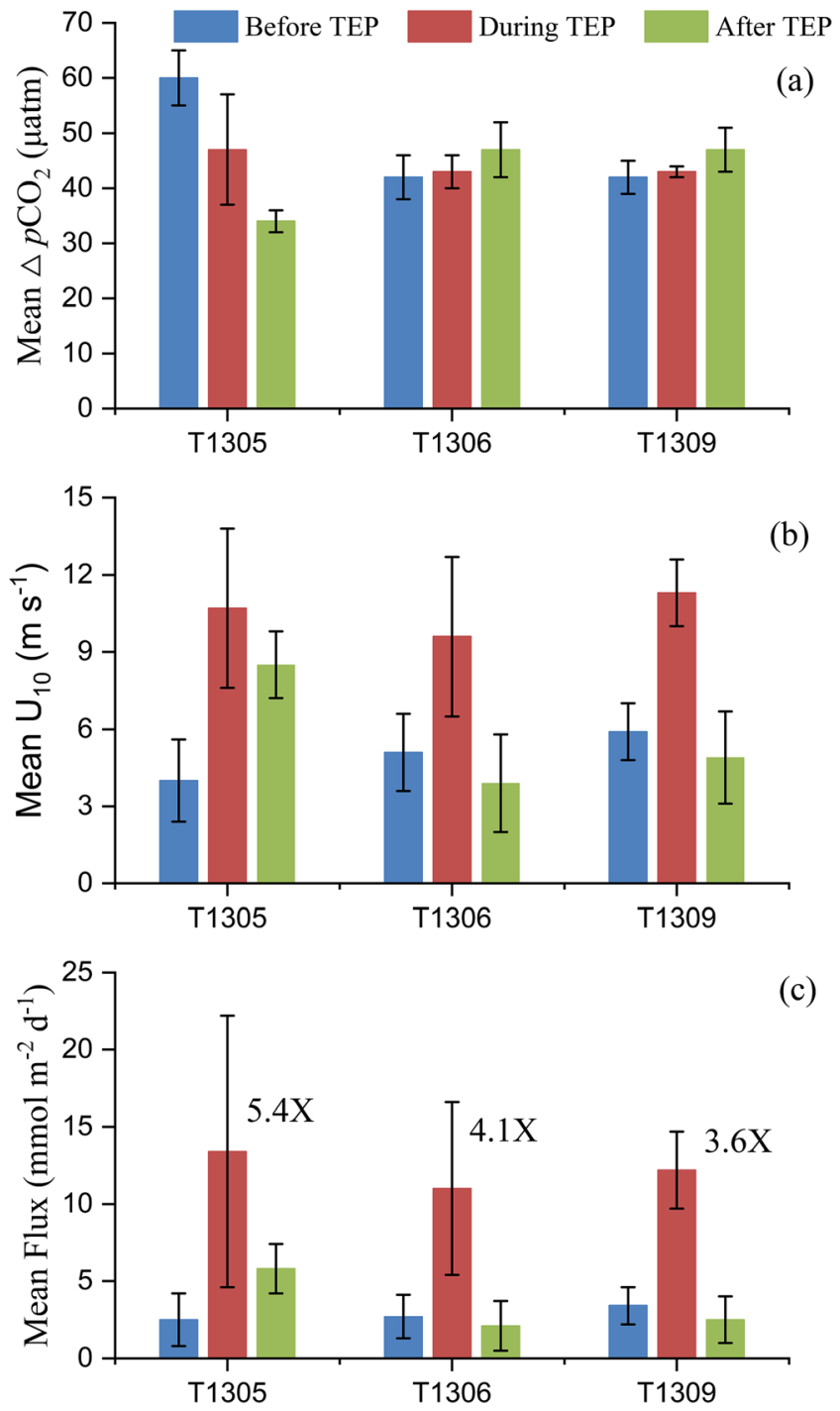

Figure 6. Comparison of mean $\Delta p \mathrm{CO}_{2}$ (a), mean $U_{10}$ (b), and mean flux (c) before, during and after the TEP of three typhoons described in the text. Error bars are standard deviations. The numbers in (c) represent multiples of the mean $\mathrm{CO}_{2}$ flux during the typhoon compared to the pretyphoon values. important than the maximum typhoon wind speed. It is worth pointing out that the two buoy sites in this study were located at the northern SCS slope area, which is typically oligotrophic and low in productivity. This discussion is thus representative of the oligotrophic part of the SCS.

\subsection{Effects of Typhoons on Air-Sea $\mathrm{CO}_{2}$ Fluxes}

The mean air-sea $\mathrm{CO}_{2}$ flux excluding TEPs in the northern SCS during the study period was $3.9 \pm 3.2 \mathrm{mmol} \mathrm{m}^{-2}$ day $^{-1}$, close to the value of $3.2 \pm 0.3 \mathrm{mmol} \mathrm{m}^{-2}$ day $^{-1}$ determined from summertime field surveys measurements from offshore water in the SCS (Zhai et al., 2013). During three TEPs, the $\mathrm{CO}_{2}$ flux ranged from 3.0 (T1309) to 41.7 (T1305) mmol m ${ }^{-2} \mathrm{day}^{-1}$, with a mean of 11.0 $13.4 \mathrm{mmol} \mathrm{m}^{-2}$ day $^{-1}$, which was about 3 times the mean flux under nontyphoon conditions. Generally, the air-sea $\mathrm{CO}_{2}$ flux varied with wind speed (Figure 3). The highest flux occurred on the days when typhoons passed nearby the buoy, corresponding to the highest $U_{10}$ (Figure 3). In contrast, the fluxes were low in May and June even though $\Delta \mathrm{pCO}_{2}$ of those months were the highest (the maximum value was $106 \mu \mathrm{atm}$ ) of the study period. Typhoons had a minor effect on $\mathrm{CCO}_{2}{ }^{\text {air }}$ (Figure 3). Typhoons affect air-sea $\mathrm{CO}_{2}$ fluxes mainly through their effects on $\mathrm{pCO}_{2}$ and $U_{10}$ (Figure 4). The typhoons in this study either reduced (T1305) or only slightly changed surface $\Delta p \mathrm{CO}_{2}$ (T1306 and T1309, Figure 6a). As such, the increase in $\mathrm{CO}_{2}$ flux during typhoons resulted primarily from elevated $U_{10}$ (Figures $6 \mathrm{~b}$ and $6 \mathrm{c}$ ).

The mean $\mathrm{CO}_{2}$ fluxes before, during, and after each typhoon showed similar changes (Figure 6c). The flux was less than $4 \mathrm{mmol} \mathrm{m}^{-2}$ day $^{-1}$ before the passage of each typhoon. The overall mean $\mathrm{CO}_{2}$ flux was only $2.9 \pm 0.5 \mathrm{mmol} \mathrm{m}^{-2}$ day ${ }^{-1}$ before the typhoons passage (determined over a period of time before each TEP with a length of thevTEP). However, the overall mean increased to $12.2 \pm 1.2 \mathrm{mmol} \mathrm{m}^{-2}$ day $^{-1}$ during TEPs (Figure 6c). After typhoons, it decreased to $3.5 \pm 2.0 \mathrm{mmol} \mathrm{m}^{-2}$ day $^{-1}$ (determined over a period of time following the TEP of length of the TEP), which was slightly higher than the values before typhoons. Mean $\mathrm{CO}_{2}$ flux during TEPs amounted to 3.6 to 5.4 times pretyphoon values (Figure 6c), corresponding to a 1.9-2.7-fold increase in $U_{10}$ from pretyphoon values. Overall, all three typhoons dramatically increased the magnitude of $\mathrm{CO}_{2}$ efflux.

During each TEP, the maximum decrease of $p \mathrm{CO}_{2}$ (maximum $p \mathrm{CO}_{2}-$ minimum $p \mathrm{CO}_{2}$ ) was $32 \mu$ atm for T1305, $11 \mu \mathrm{atm}$ for T1306, and $3 \mu \mathrm{atm}$ for T1309 (Figure 4). A strong linear correlation was seen between $\Delta \mathrm{CO}_{2}$ and the minimum distance between the typhoon center and the buoy site (Figure 7). The surface $\mathrm{CO}_{2}$ flux increase factor (the multiples of the mean $\mathrm{CO}_{2}$ flux during TEP compared to the values before TEP) (Figure 6c) was also strongly correlated with the nearest distance to typhoon (Figure 7). The increase factor was not likely related to the strength of the typhoon, as all three typhoons were classified as tropical storms and were of similar intensity. Our results thus indicate that the effect of typhoons on $\mathrm{CO}_{2}$ flux varies spatially, although additional studies are needed to fully assess this spatial variation.

In this study, the TEP lasted 75, 65 and $57 \mathrm{hr}$ for Typhoons T1305, T1306, and T1309, respectively, totaling $197 \mathrm{hr}$, only $9 \%$ of the 94-day study period. The cumulative $\mathrm{CO}_{2}$ efflux during the study period (Figure 8) shows significant influence of typhoons on the total $\mathrm{CO}_{2}$ flux, which amounted to $429 \mathrm{mmol} \mathrm{m}^{-2}$ to the atmosphere over the 94 days. The cumulative $\mathrm{CO}_{2}$ flux was 41, 26, and $28 \mathrm{mmol} \mathrm{m}{ }^{-2}$ during T1305, T1306, and T1309, respectively. These totaled to $95 \mathrm{mmol} \mathrm{m}^{-2}$, which equals $22 \%$ of the total $\mathrm{CO}_{2}$ efflux 


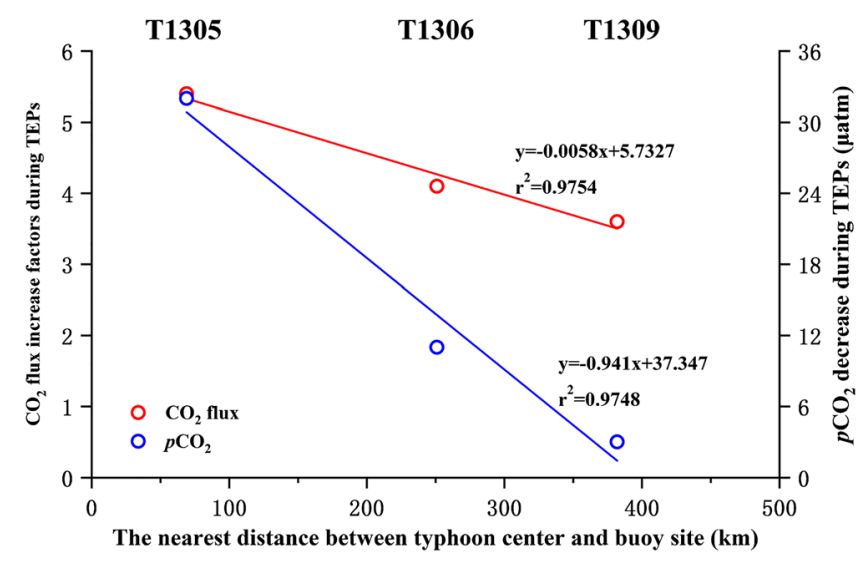

Figure 7. The nearest distance between three typhoon centers and the buoy site versus surface $p \mathrm{CO}_{2}$ decrease and $\mathrm{CO}_{2}$ flux increase factors (Figure 6c) during TEPS. during the study period cited above. Zhai et al., 2013 estimated that the annual air-sea $\mathrm{CO}_{2}$ flux was $460 \pm 430 \mathrm{mmol} \mathrm{m}^{-2}$ year ${ }^{-1}$ in the northern SCS. This estimate was based on multiple underway surveys but did not consider the effect of typhoons on $\mathrm{CO}_{2}$ flux. The $\mathrm{CO}_{2}$ flux of these three typhoons correspondingly accounted for $21 \pm 22 \%$ of the annual air-sea $\mathrm{CO}_{2}$ flux estimated by Zhai et al.

The relative contribution of three typhoons to the total $\mathrm{CO}_{2}$ flux $(22 \%)$ in this study was not as high as the effect of cyclones in the East China Sea (60\%) (Nemoto et al., 2009) and the Sargasso Sea (44\%) (Bates et al., 1998). However, the magnitude of their contribution (95 mmol m${ }^{-2}$ ) was comparable to that of three typhoons in the East China Sea $\left(90 \mathrm{mmol} \mathrm{m}^{-2}\right.$ ) (Nemoto et al., 2009). The $\mathrm{CO}_{2}$ flux during the East China Sea typhoons constituted a larger fraction of the total flux because of the relatively small efflux of $\mathrm{CO}_{2}$ flux from the East Chain Sea in the warm season $\left(150 \mathrm{mmol} \mathrm{m}^{-2}\right.$ from mid-July through mid-September, when that area acted as a $\mathrm{CO}_{2}$ source). In the Sargasso Sea, three hurricanes contributed $145 \mathrm{mmol} \mathrm{m}^{-2} \mathrm{CO}_{2}$ flux from ocean to atmosphere, based on shipboard observations before and after the storms passed (Bates et al., 1998). Typhoons or hurricanes in the above study areas all increased $\mathrm{CO}_{2}$ efflux. Although each storm is unique and can generate different effects on surface $p \mathrm{CO}_{2}$ and $\mathrm{CO}_{2}$ flux, all of the above studies found that the storm effect accounted for a significant portion of the total $\mathrm{CO}_{2}$ flux during the study periods.

\subsection{Interannual Variations of Typhoon's Impact on Air-Sea $\mathrm{CO}_{2}$ Flux}

Both the current study (Figure 3) and previous studies (Bates et al., 1998; Nemoto et al., 2009) indicate that air-sea $\mathrm{CO}_{2}$ fluxes are mostly controlled by wind speeds, while the effect of the air-sea $\mathrm{CO}_{2}$ gradient $\left(\Delta p \mathrm{CO}_{2}\right)$ is secondary during tropical cyclones. This provides the capacity to estimate the interannual variability of the impact of typhoons on air-sea $\mathrm{CO}_{2}$ flux in the northern SCS using only long-term wind and SST data products. Herein, to estimate a 10-year (2008-2018) time series of $\mathrm{CO}_{2}$ flux near the buoy locations during TEPs, we used the long-term $U_{10}$ and SST data from two well-established data repositories. The $U_{10}$ data were extracted from the National Centers for Environmental Prediction (NCEP, https://www.ncep.noaa. gov) reanalysis data base. We utilized the $U_{10}$ series (6-hr interval) from the NCEP grid cell encompassing the buoy locations, with its center $75 \mathrm{~km}$ from the centroid of the buoys. The $U_{10}$ series from this cell aligns closely with $U_{10}$ series derived from buoy measurements, capturing the primary temporal trends as well as the signal of the three principal typhoons (Figure 3d), although the strong winds of Typhoon T1305 appear in the NCEP series two days after they are seen in the in situ measurements. The SST data were obtained from the National Oceanic and Atmospheric Administration (NOAA) Earth Systems Research Laboratory (ERSL, https://www.esrl.noaa.gov/) daily averaged, optimally interpolated SST data base. The SST series from the $0.25^{\circ} \times 0.25^{\circ}$ cell with the center closest (within $35 \mathrm{~km}$ ) to the buoys' centroid was employed in the flux calculation. The SST series was first interpolated to the times of the $U_{10}$ series. The ERSL SST series aligns well with the measured SSTs, although it does not capture the high-frequency (periods of a day or less) variability of the measured series (Figure 3b).

In modeling air-sea $\mathrm{CO}_{2}$ flux during all TEPs with the 10-year SST and $U_{10}$ series described above, we assumed an air-sea $\Delta p \mathrm{CO}_{2}$ of $44 \mu \mathrm{atm}$, which is equal to the mean $\Delta p \mathrm{CO}_{2}$ determined during the TEPs of our study ( $\pm 7 \mu \mathrm{atm}, \mathrm{SD})$. To estimate the yearly total $\mathrm{CO}_{2}$ flux associated with the passage of typhoons, the yearly number of typhoons traversing the SCS was determined from the JTWC track data and the annual total TEP was calculated from the $U_{10}$ data (section 2.3). For comparison, the modeled total $\mathrm{CO}_{2}$ flux during three TEPs in 2013 was $105 \mathrm{mmol} \mathrm{m}^{-2}$, which gave a difference of $\sim 10 \%$ compared to the in situ measurements in this study $\left(95 \mathrm{mmol} \mathrm{m}{ }^{-2}\right.$ ). This suggests that our method of estimating $\mathrm{CO}_{2}$ fluxes during TEPs is reasonable.

The estimates of the total accumulated annual air-sea $\mathrm{CO}_{2}$ flux during the TEPs show considerable interannual variation, ranging from 104 to $259 \mathrm{mmol} \mathrm{m}^{-2}$ (164 $\mathrm{mmol} \mathrm{m}^{-2}$ on average) (Figure $9 \mathrm{~d}$ ). Much of this 


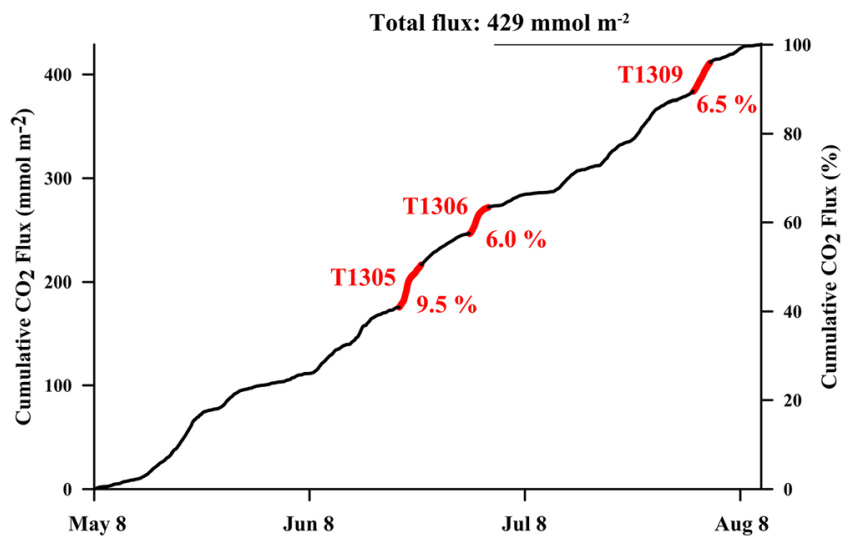

Figure 8. Cumulative $\mathrm{CO}_{2}$ flux (the sum of hourly values) over the study period from 8 May through 10 August 2013. There were some gaps in the time series of $p \mathrm{CO}_{2}$ and $U_{10}$ and thus in the calculated $\mathrm{CO}_{2}$ flux. We linearly interpolated the data to fill the gaps in order to calculate cumulative flux. variation is due to the interannual variation in total TEP, $U_{10}$, and the number of typhoons (i.e., typhoon frequency) traversing the SCS. It is worth noting that no single factor among these has a dominant effect on $\mathrm{CO}_{2}$ flux during TEPs (Figure 9). Locally, $\mathrm{CO}_{2}$ efflux increases with the number of typhoons (Koch et al., 2009). Over 2008-2018, three to seven typhoons passed over the northern SCS annually (Figure 9a), while the annual total TEP associated with these typhoons ranged between 174 and $402 \mathrm{hr}$ (Figure 9c). The annual averaged $U_{10}$ during TEPs ranged between 9.6 and $13.8 \mathrm{~m} \mathrm{~s}^{-1}$ (11.9 $\mathrm{m} \mathrm{s}^{-1}$ on average, Figure 9b), which was comparable to that observed on the buoy. Typhoon-enhanced air-sea $\mathrm{CO}_{2}$ flux was highest in 2013 (Figure 9d), which had both higher $U_{10}$ and total TEP.

Overall, the impact of typhoons in the northern SCS is shown to be significant relative to annual $\mathrm{CO}_{2}$ fluxes and highly variable interannually. The above yearly estimated fluxes during the TEPs account for $23-56 \%$ (36\% on average, Figure 9d) of the annual $\mathrm{CO}_{2}$ flux (460 $\mathrm{mmol} \mathrm{m}^{-2}$, Zhai et al., 2013) from the northern SCS, while only 2.0-4.6\% of time was categorized as TEP. The contribution of typhoons to annual air-sea $\mathrm{CO}_{2}$ flux in most years of the last decade was between $30 \%$ and $45 \%$ (with the exceptions of 2013, 56\%, and 2014, 23\%) without an apparent long-term trend. Such large variability caused by typhoon's effects likely exerts an important
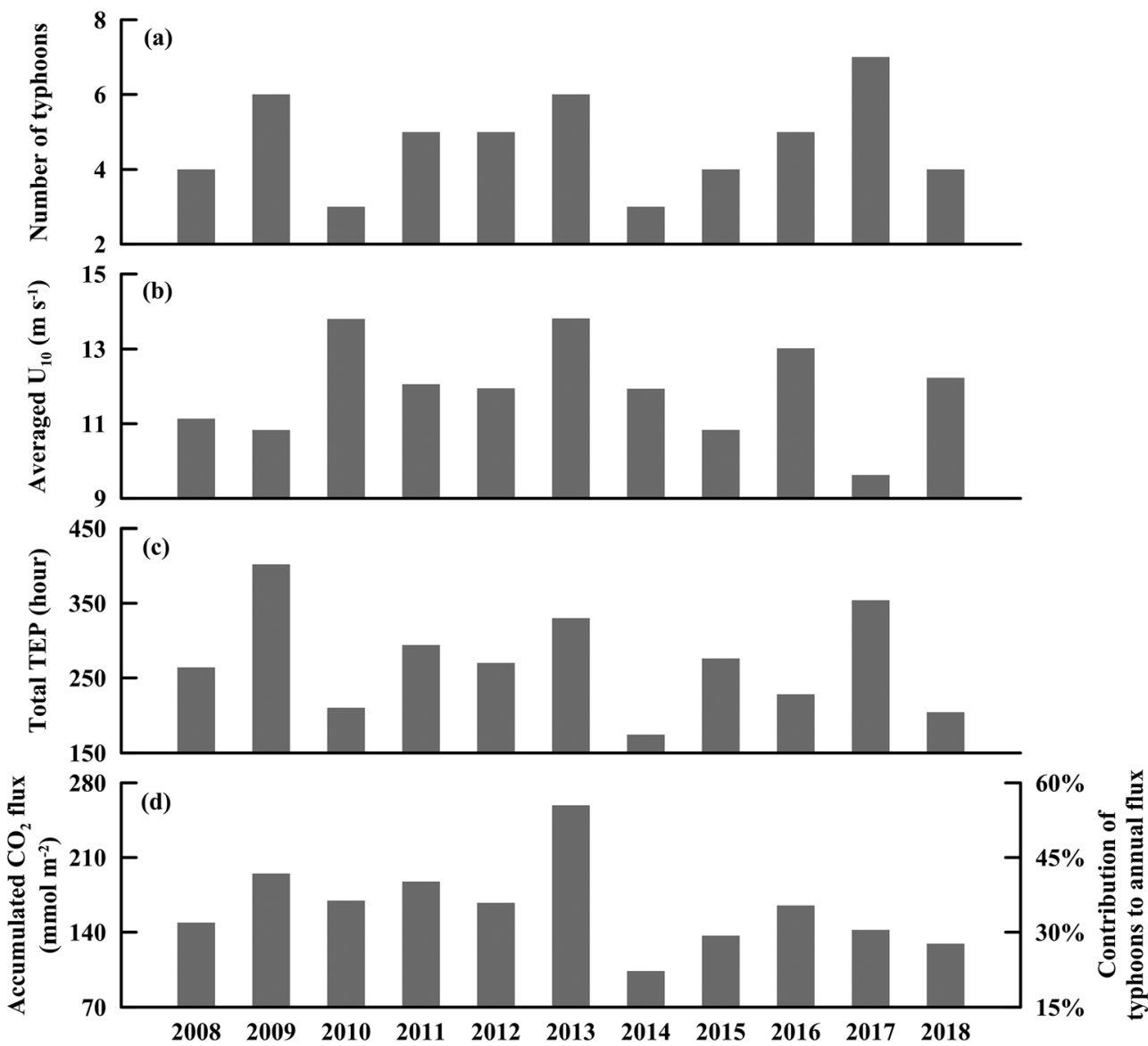

Figure 9. Interannual variability (2008-2018) of (a) number of typhoons traversing the northern SCS, (b) annual mean $U_{10}$ during the TEPs, (c) the annual total TEP, and (d) the total accumulated air-sea $\mathrm{CO}_{2}$ flux during the TEPs of each year (the left vertical axis represents the total values, and the right denotes the relative contribution to the annual total $\mathrm{CO}_{2}$ flux). 
control on interannual variability of the annual $\mathrm{CO}_{2}$ flux budget in the region, as it is generally larger than the seasonal variability of $\mathrm{CO}_{2}$ flux (Figure 3). As such, typhoons may play a major role of affecting air-sea $\mathrm{CO}_{2}$ flux from the SCS over both short and long terms.

\section{Conclusions}

This study conducted an in-depth analysis on the effects of typhoons on surface $p \mathrm{CO}_{2}$ and $\mathrm{CO}_{2}$ fluxes in the northern SCS, the largest tropical marginal sea in the world. During the entire study period from May to August 2013, the study region was a source of $\mathrm{CO}_{2}$ to the atmosphere. Under nontyphoon conditions, temperature generally played a primary role in controlling surface water $\mathrm{pCO}_{2}$, including its daily cycle, while biological and physical effects were secondary, consistent with the study area as an oligotrophic tropical shelf region.

The study site was affected by three major typhoons during the study period. Their effects were reflected in both surface $p \mathrm{CO}_{2}$ and $\mathrm{CO}_{2}$ fluxes. The typhoons seemed to have a three-step impact on surface $p \mathrm{CO}_{2}$, where the first step at the beginning period of a typhoon was to lower SST thus surface $p \mathrm{CO}_{2}$ and the second step likely resulted from vertical mixing that brought up water with high $\mathrm{CO}_{2}$ concentrations from depth. In the third step, this water, enriched in $\mathrm{CO}_{2}$ and nutrients, likely triggered net biological $\mathrm{CO}_{2}$ uptake that lowered surface $\mathrm{pCO}_{2}$. Although temperature continued to play an important role in controlling surface $p \mathrm{CO}_{2}$ during typhoon periods, mixing and biology seem to exert significant impacts on $\mathrm{pCO}_{2}$ at times. Such a proposed multistep process is consistent with studies in other regions, although more detailed studies are required to further examine the mechanisms controlling changes in surface $p \mathrm{CO}_{2}$.

The typhoons' effect on air-sea $\mathrm{CO}_{2}$ flux occurred mainly through increased $U_{10}$, and thus greater $\mathrm{CO}_{2}$ efflux, during each typhoon. The mean $\mathrm{CO}_{2}$ flux during a typhoon observed in this study reached 3.6 to 5.4 times the pretyphoon mean flux. The magnitude of the typhoon effect was strongly correlated with the distance to typhoon center. The typhoon effect translated to about $22 \%$ of the total $\mathrm{CO}_{2}$ flux during the study period, which was influenced by typhoons only $9 \%$ of the time. A long-term analysis revealed that the effect of typhoons accounted for $23-56 \%$ of the annual air-sea $\mathrm{CO}_{2}$ efflux in the northern SCS during the last decade (2008-2018), indicating that typhoons substantially enhanced the flux of $\mathrm{CO}_{2}$ to the atmosphere. Typhoons and other tropical cyclones thus likely play a major role in determining the annual $\mathrm{CO}_{2}$ fluxes both in the short and long terms in the SCS and beyond. These results support the prediction that tropical cyclones will play an increasingly important role in controlling air-sea $\mathrm{CO}_{2}$ fluxes in a warmer and stormier ocean.

\section{Data Availability Statement}

The data in this study are available online (at https://figshare.com/s/b9fa471ebd38442ca0ff).

\begin{abstract}
Acknowledgments
The authors express their gratitude to the crew members of the research vessel Huizhi and to Tao Ding, Beifeng Zhou, and Ruzhou Dong for their assistance in deployment and technical support. We thank Mallory Ringham and Kate Morkeski for editing. We also express our gratitude to two anonymous reviewers for their insightful comments and suggestions. This study was supported by the Marine Public Welfare Project of China (Grant 200905012), the Scientific Research Fund of the Second Institute of Oceanography of China (Grant JT1502), the Global Change and Air-Sea Interaction project of China (Grant GASI-03-01-02-02), and the National Natural Sciences Foundation of China (Grant 91128212).
\end{abstract}

\section{References}

Bai, Y., Huang, T. H., He, X. Q., Wang, S. L., Hsin, Y. C., Wu, C. R., et al. (2015). Intrusion of the Pearl River plume into the main channel of the Taiwan Strait in summer. Journal of Sea Research, 95, 1-15. https://doi.org/10.1016/j.seares.2014.10.003

Bates, N. R., Knap, A. H., \& Michaels, A. F. (1998). Contribution of hurricanes to local and global estimates of air-sea exchange of $\mathrm{CO}_{2}$. Nature, 395(6697), 58-61. https://doi.org/10.1038/25703

Bauer, J. E., Cai, W. J., Raymond, P. A., Bianchi, T. S., Hopkinson, C. S., \& Regnier, P. A. G. (2013). The changing carbon cycle of the coastal ocean. Nature, 504(7478), 61-70. https://doi.org/10.1038/nature12857

Cai, W. J., Dai, M. H., \& Wang, Y. C. (2006). Air-sea exchange of carbon dioxide in ocean margins: A province-based synthesis. Geophysical Research Letters, 33, L12603. https://doi.org/10.1029/2006GL026219

Cai, W. J., Hu, X. P., Huang, W. J., Murrell, M. C., Lehrter, J. C., Lohrenz, S. E., et al. (2011). Acidification of subsurface coastal waters enhanced by eutrophication. Nature Geoscience, 4(11), 766-770. https://doi.org/10.1038/NGEO1297

Cao, Z. M., Dai, M. H., Zheng, N., Wang, D. L., Li, Q., Zhai, W. D., et al. (2011). Dynamics of the carbonate system in a large continental shelf system under the influence of both a river plume and coastal upwelling. Journal of Geophysical Research, 116, G02010. https://doi. org/10.1029/2010JG001596

Chang, Y., Liao, H. T., Lee, M. A., Chan, J. W., Shieh, W. J., Lee, K. T., et al. (2008). Multisatellite observation on upwelling after the passage of Typhoon Hai-Tang in the southern East China Sea. Geophysical Research Letters, 35, L03612. https://doi.org/10.1029/2007GL032858

Chen, C. T. A., \& Borges, A. V. (2009). Reconciling opposing views on carbon cycling in the coastal ocean: Continental shelves as sinks and near-shore ecosystems as sources of atmospheric $\mathrm{CO}_{2}$. Deep-Sea Research Part II: Topical Studies in Oceanography, 56(8-10), 578-590. https://doi.org/10.1016/j.dsr2.2009.01.001

Chen, C. T. A., Gao, X. L., Ishizaka, J., \& Lebel, L. (2015). Coastal seas in a changing world: Anthropogenic impact and environmental responses. Continental Shelf Research, 111, 109-111. https://doi.org/10.1016/j.csr.2015.11.007 
Chen, C. T. A., Liu, C. T., Chuang, W. S., Yang, Y. J., Shiah, F. K., Tang, T. Y., \& Chung, S. W. (2003). Enhanced buoyancy and hence upwelling of subsurface Kuroshio waters after a typhoon in the southern East China Sea. Journal of Marine Systems, 42(1-2), 65-79. https://doi.org/10.1016/S0924-7963(03)00065-4

Chen, C. T. A., Wang, S. L., Chou, W. C., \& Sheu, D. D. (2006). Carbonate chemistry and projected future changes in $\mathrm{pH}^{\mathrm{and}} \mathrm{CaCO}_{3}$ saturation state of the South China Sea. Marine Chemistry, 101(3-4), 277-305. https://doi.org/10.1016/j.marchem.2006.01.007

Chen, C. T. A., Wang, S. L., Wang, B. J., \& Pai, S. C. (2001). Nutrient budgets for the South China Sea basin. Marine Chemistry, 75(4), 281-300. https://doi.org/10.1016/S0304-4203(01)00041-X

Chen, Y. L. L., \& Chen, H. Y. (2006). Seasonal dynamics of primary and new production in the northern South China Sea: The significance of river discharge and nutrient advection. Deep-Sea Research Part I: Oceanographic Research Papers, 53(6), 971-986. https://doi.org/ 10.1016/j.dsr.2006.02.005

Chou, W. C., Sheu, D. D. D., Chen, C. T. A., Wang, S. L., \& Tseng, C. M. (2005). Seasonal variability of carbon chemistry at the SEATS time-series site, northern South China Sea between 2002 and 2003. Terrestrial, Atmospheric and Oceanic Sciences, 16(2), 445-465.

Dai, M. H., Cao, Z. M., Guo, X. H., Zhai, W. D., Liu, Z. Y., Yin, Z. Q., et al. (2013). Why are some marginal seas sources of atmospheric CO ${ }_{2}$ ? Geophysical Research Letters, 40, 2154-2158. https://doi.org/10.1002/grl.50390

Dai, M. H., Lu, Z. M., Zhai, W. D., Chen, B. S., Cao, Z. M., Zhou, K. B., et al. (2009). Diurnal variations of surface seawater $p \mathrm{CO}_{2}$ in contrasting coastal environments. Limnology and Oceanography, 54(3), 735-745. https://doi.org/10.4319/lo.2009.54.3.0735

Dai, M. H., Zhai, W. D., Cai, W. J., Callahan, J., Huang, B. Q., Shang, S. L., et al. (2008). Effects of an estuarine plume-associated bloom on the carbonate system in the lower reaches of the Pearl River estuary and the coastal zone of the northern South China Sea. Continental Shelf Research, 28(12), 1416-1423. https://doi.org/10.1016/j.csr.2007.04.018

Du, C., Liu, Z., Dai, M. H., Kao, S. J., Cao, Z. M., Zhang, Y., et al. (2013). Impact of the Kuroshio intrusion on the nutrient inventory in the upper northern South China Sea: Insights from an isopycnal mixing model. Biogeosciences, 10(10), 6419-6432. https://doi.org/10.5194/ bg-10-6419-2013

Guo, X. H., Cai, W. J., Zhai, W. D., Dai, M. H., Wang, Y. C., \& Chen, B. S. (2008). Seasonal variations in the inorganic carbon system in the Pearl River (Zhujiang) estuary. Continental Shelf Research, 28(12), 1424-1434. https://doi.org/10.1016/j.csr.2007.07.011

Han, W. Y. (1998). Marine chemistry in the South China Sea (p. 289). Beijing: Science Press. (in Chinese)

Han, W. Y., \& Ma, K. M. (1988). Studies on the coastal upwelling along the coasts of the east Guangdong Province (in Chinese). Acta Oceanography Sinica, 10(1), 52-59.

He, X. Q., Xu, D. F., Bai, Y., Pan, D. L., Chen, C. T. A., Chen, X. Y., \& Gong, F. (2016). Eddy-entrained Pearl River plume into the oligotrophic basin of the South China Sea. Continental Shelf Research, 124, 117-124. https://doi.org/10.1016/j.csr.2016.06.003

Ho, D. T., Law, C. S., Smith, M. J., Schlosser, P., Harvey, M., \& Hill, P. (2006). Measurements of air-sea gas exchange at high wind speeds in the Southern Ocean: Implications for global parameterizations. Geophysical Research Letters, 33, L16611. http://doi.org/10.1029/ $2006 \mathrm{gl026817}$

Hood, E. M., Wanninkhof, R., \& Merlivat, L. (2001). Short timescale variations of $\mathrm{f}\left(\mathrm{CO}_{2}\right)$ in a North Atlantic warm-core eddy: Results from the Gas-Ex 98 carbon interface ocean atmosphere (CARIOCA) buoy data. Journal of Geophysical Research, 106(C2), 2561-2572. https:// doi.org/10.1029/1999JC000278

Huang, P. S., \& Imberger, J. (2010). Variation of $\mathrm{pCO}_{2}$ in ocean surface water in response to the passage of a hurricane. Journal of Geophysical Research, 115, C10024. https://doi.org/10.1029/2010JC006185

Iida, Y., Kojima, A., Takatani, Y., Nakano, T., Sugimoto, H., Midorikawa, T., \& Ishii, M. (2015). Trends in $p \mathrm{CO}_{2}$ and air-sea $\mathrm{CO}_{2}$ flux over the global open oceans for the last two decades. Journal of Oceanography, 71(6), 637-661. https://doi.org/10.1007/s10872-015-0306-4

Intergovernmental Panel on Climate Change (IPCC) (2013). Summary for policymakers. In T. F. Stocker, D. Qin, G.-K. Plattner, M. Tignor, S. K. Allen, J. Boschung, et al. (Eds.), Climate change 2013: The physical science basis. Contribution of Working Group I to the Fifth Assessment Report of the Intergovernmental Panel on Climate Change. (7). Cambridge, United Kingdom and New York, NY, USA: Cambridge University Press.

Koch, J., McKinley, G. A., Bennington, V., \& Ullman, D. (2009). Do hurricanes cause significant interannual variability in the air-sea $\mathrm{CO}_{2}$ flux of the subtropical North Atlantic? Geophysical Research Letters, 36, L07606. https://doi.org/10.1029/2009GL037553

Large, W. G., \& Pond, S. (1981). Open ocean momentum flux measurements in moderate to strong winds. Journal of Physical Oceanography, 11(3), 324-336. https://doi.org/10.1175/1520-0485(1981)011\%3C0324:OOMFMI\%3E2.0.CO;2

Laruelle, G. G., Lauerwald, R., Pfeil, B., \& Regnier, P. (2014). Regionalized global budget of the $\mathrm{CO}_{2}$ exchange at the air-water interface in continental shelf seas. Global Biogeochemical Cycles, 28, 1199-1214. https://doi.org/10.1002/2014GB004832

Lin, I., Liu, W. T., Wu, C. C., Wong, G. T. F., Hu, C. M., Chen, Z. Q., et al. (2003). New evidence for enhanced ocean primary production triggered by tropical cyclone. Geophysical Research Letters, 30(13), 1718. https://doi.org/10.1029/2003GL017141

Nemoto, K., Midorikawa, T., Wada, A., Ogawa, K., Takatani, S., Kimoto, H., et al. (2009). Continuous observations of atmospheric and oceanic $\mathrm{CO}_{2}$ using a moored buoy in the East China Sea: Variations during the passage of typhoons. Deep-Sea Research Part II: Topical Studies in Oceanography, 56(8-10), 542-553. https://doi.org/10.1016/j.dsr2.2008.12.015

Shang, S. L., Li, L., Li, J., Li, Y. H., Lin, G., \& Sun, J. (2012). Phytoplankton bloom during the northeast monsoon in the Luzon Strait bordering the Kuroshio. Remote Sensing of Environment, 124, 38-48. https://doi.org/10.1016/j.rse.2012.04.022

Sheu, W. J., Wu, C. R., \& Oey, L. Y. (2010). Blocking and westward passage of eddies in the Luzon Strait. Deep-Sea Research Part II: Topical Studies in Oceanography, 57(19-20), 1783-1791. https://doi.org/10.1016/j.dsr2.2010.04.004

Su, J. (2004). Overview of the South China Sea circulation and its influence on the coastal physical oceanography outside the Pearl River Estuary. Continental Shelf Research, 24(16), 1745-1760. https://doi.org/10.1016/j.csr.2004.06.005

Sun, Q. Y., Tang, D. L., Legendre, L., \& Shi, P. (2014). Enhanced air-sea $\mathrm{CO}_{2}$ exchange influenced by a tropical depression in the South China Sea. Journal of Geophysical Research: Oceans, 119, 6792-6804. https://doi.org/10.1002/2014JC010131

Sweeney, C., Gloor, E., Jacobson, A. R., Key, R. M., McKinley, G., Sarmiento, J. L., \& Wanninkhof, R. (2007). Constraining global air-sea gas exchange for CO2 with recent bomb 14C measurements. Global Biogeochemical Cycles, 21, GB2015. https://doi.org/10.1029/2006GB 002784

Takahashi, T., Olafsson, J., Goddard, J. G., Chipman, D. W., \& Sutherland, S. C. (1993). Seasonal variation of $\mathrm{CO}_{2}$ and nutrients in the high-latitude surface ocean: A comparative study. Global Biogeochemical Cycles, 7(4), 843-878. https://doi.org/10.1029/93gb02263

Takahashi, T., Sutherland, S. C., Wanninkhof, R., Sweeney, C., Feely, R. A., Chipman, D. W., et al. (2009). Climatological mean and decadal change in surface ocean $\mathrm{pCO}_{2}$, and net air-sea $\mathrm{CO}_{2}$ flux over the global oceans. Deep-Sea Research Part II: Topical Studies in Oceanography, 56(8-10), 554-577. https://doi.org/10.1016/j.dsr2.2008.12.009 
Tseng, C. M., Wong, G. T. F., Chou, W. C., Lee, B. S., Sheu, D. D., \& Liu, K. K. (2007). Temporal variations in the carbonate system in the upper layer at the SEATS station. Deep-Sea Research Part II: Topical Studies in Oceanography, 54(14-15), 1448-1468. https://doi.org/ 10.1016/j.dsr2.2007.05.003

Wanninkhof, R. (1992). Relationship between wind speed and gas exchange over the ocean. Journal of Geophysical Research, 97(C5), 7373-7382. http://doi.org/10.1029/92jc00188

Wanninkhof, R. (2014). Relationship between wind speed and gas exchange over the ocean revisited. Limnology and Oceanography: Methods, 12(6), 351-362. https://doi.org/10.4319/lom.2014.12.351

Wanninkhof, R., Park, G. H., Takahashi, T., Sweeney, C., Feely, R., Nojiri, Y., et al. (2013). Global ocean carbon uptake: Magnitude, variability and trends. Biogeosciences, 10(3), 1983-2000. https://doi.org/10.5194/bg-10-1983-2013

Weiss, R. F. (1974). Carbon dioxide in water and seawater: The solubility of a non-ideal gas. Marine Chemistry, 2(3), 203-215. https://doi. org/10.1016/0304-4203(74)90015-2

Wong, G. T. F., Ku, T. L., Mulholland, M., Tseng, C. M., \& Wang, D. P. (2007). The SouthEast Asian time-series study (SEATS) and the biogeochemistry of the South China Sea-An overview. Deep-Sea Research Part II: Topical Studies in Oceanography, 54(14-15), 1434-1447. https://doi.org/10.1016/j.dsr2.2007.05.012

Zhai, W. D., Dai, M. H., Cai, W. J., Wang, Y. C., \& Hong, H. S. (2005). The partial pressure of carbon dioxide and air-sea fluxes in the northern South China Sea in spring, summer and autumn. Marine Chemistry, 96(1-2), 87-97. https://doi.org/10.1016/j. marchem.2004.12.002

Zhai, W. D., Dai, M. H., Chen, B. S., Guo, X. H., Li, Q., Shang, S. L., et al. (2013). Seasonal variations of air-sea $\mathrm{CO}_{2}$ fluxes in the largest tropical marginal sea (South China Sea) based on multiple-year underway measurements. Biogeosciences, 10(11), 7775-7791. https://doi. org/10.5194/bg-10-7775-2013

Zhao, H., Tang, D. L., \& Wang, Y. Q. (2008). Comparison of phytoplankton blooms triggered by two typhoons with different intensities and translation speeds in the South China Sea. Marine Ecology Progress Series, 365, 57-65. https://doi.org/10.3354/meps0741838 